\title{
The Integrated Stress Response in Hypoxia-Induced Diffuse White Matter Injury
}

\author{
@Benjamin L. Clayton, ${ }^{1}$ Aaron Huang, ${ }^{1}$ Rejani B. Kunjamma, ${ }^{1}$ Ani Solanki, ${ }^{2}$ and ${ }^{\circledR B}$ Brian Popko ${ }^{1}$ \\ ${ }^{1}$ Department of Neurology, The University of Chicago Center for Peripheral Neuropathy, The University of Chicago, Chicago, Illinois 60637, and ${ }^{2}$ Animal \\ Resource Center, The University of Chicago, Chicago, Illinois 60637
}

Currently no treatments exist for preterm infants with diffuse white matter injury (DWMI) caused by hypoxia. Due to the improved care of preterm neonates and increased recognition by advanced imaging techniques, the prevalence of DWMI is increasing. A better understanding of the pathophysiology of DWMI is therefore of critical importance. The integrated stress response (ISR), a conserved eukaryotic response to myriad stressors including hypoxia, may play a role in hypoxia-induced DWMI and may represent a novel target for much needed therapies. In this study, we use in vitro and in vivo hypoxic models of DWMI to investigate whether the ISR is involved in DWMI. We demonstrate that hypoxia activates the ISR in primary mouse oligodendrocyte precursor cells (OPCs) in vitro and that genetically inhibiting the ISR in differentiating OPCs increases their susceptibility to in vitro hypoxia. We also show that a well established in vivo mild chronic hypoxia $(\mathrm{MCH})$ mouse model and a new severe acute hypoxia $(\mathrm{SAH})$ mouse model of DWMI activates the initial step of the ISR. Nonetheless, genetic inhibition of the ISR has no detectable effect on either MCH- or SAH-induced DWMI. In addition, we demonstrate that genetic enhancement of the ISR does not ameliorate MCH- or SAH-induced DWMI. These studies suggest that, while the ISR protects OPCs from hypoxia in vitro, it does not appear to play a major role in either MCH- or SAH-induced DWMI and is therefore not a likely target for therapies aimed at improving neurological outcome in preterm neonates with hypoxia-induced DWMI.

Key words: diffuse white matter injury; hypoxia; integrated stress response; oligodendrocytes

\section{Significance Statement}

Diffuse white matter injury (DWMI) caused by hypoxia is a leading cause of neurological deficits following premature birth. An increased understanding of the pathogenesis of this disease is critical. The integrated stress response (ISR) is activated by hypoxia and protects oligodendrocyte lineage cells in other disease models. This has led to an interest in the potential role of the ISR in DWMI. Here we examine the ISR in hypoxia-induced DWMI and show that while the ISR protects oligodendrocyte lineage cells from hypoxia in vitro, genetic inhibition or enhancement of the ISR has no effect on hypoxia-induced DWMI in vivo, suggesting that the ISR does not play a major role in and is not a likely therapeutic target for DWMI.

\section{Introduction}

Diffuse white matter injury (DWMI), also known as perinatal white matter injury, is a white matter disorder affecting low-birth weight premature infants born between 23 and 32 weeks of ges-

Received Aug. 30, 2016; revised June 2, 2017; accepted June 25, 2017.

Author contributions: B.L.C. and B.P. designed research; B.L.C., A.H., A.S., and R.B.K. performed research; B.L.C. analyzed data; B.L.C. and B.P. wrote the paper.

This work was funded by National Institutes of Health Grant NS-34939 to B.P. We thank Dr. David Gozal for his guidance in setting up and using the hypoxic models, as well as Dr. David Rowitch for providing the Olig2/Cre mice, Dr. Douglas Cavener for providing the Perk ${ }^{F L / F L}$ mice, and Dr. David Ron for providing the GADD34-null mice. We also thank Gloria Wright for her help in preparing the figures.

The authors declare no competing financial interests.

Correspondence should be addressed to Brian Popko, Center for Peripheral Neuropathy, Department of Neurology, University of Chicago, 5841 South Maryland Avenue, MC2030, Chicago, IL 60637. E-mail: bpopko@neurology.bsd.uchicago.edu.

DOI:10.1523/JNEUROSCI.2738-16.2017

Copyright $\odot 2017$ the authors $\quad 0270-6474 / 17 / 377465-16 \$ 15.00 / 0$ tation. Importantly, with improved care of premature neonates, the prevalence of DWMI is increasing as more low-birth weight premature infants survive, approximately half of whom manifest cognitive and learning disabilities by school age (Wilson-Costello et al., 2005; Deng, 2010; Back, 2015). Although the cellular and molecular mechanisms that cause DWMI are unknown, hypoxia, caused by underdeveloped neural vasculature and inefficient oxygenation from immature lungs, is thought to play a major role (Volpe, 2001, 2009; Scafidi et al., 2014). Currently, there are no approved therapies for DWMI.

Susceptibility to DWMI occurs before the onset of myelination when the most prevalent member of the oligodendrocyte lineage is the oligodendrocyte progenitor cell (OPC; Back et al., 2001, 2002, 2005, 2007). The hypoxic insults damage OPCs, causing death and inhibiting their maturation, leading to decreased white matter (Back and Miller, 2014). This coupled with the known increased susceptibility of OPCs to oxidative stress is 
thought to be the underlying cause of OPC-specific damage in individuals with DWMI (Back et al., 2007; Deng, 2010).

Hypoxia, through protein kinase RNA-activated (PKR)-like endoplasmic reticulum (ER) kinase (PERK; also known as EIF2AK3), is also a known activator of the integrated stress response (ISR), a conserved eukaryotic stress response that signals through phosphorylation of the $\alpha$-subunit of eukaryotic translation initiation factor $2 \alpha$ (eIF2 $\alpha$; Koumenis et al., 2002). PERK is also a component of the unfolded protein response (UPR) and phosphorylated eIF $2 \alpha$ (p-eIF $2 \alpha$ ) decreases global protein translation and upregulates cytoprotective gene expression through activating transcription factor 4 (ATF4; Donnelly et al., 2013). ATF4 also increases the expression of the transcription factor CAAT enhancer binding protein homologous protein (CHOP; also known as DDIT3; Harding et al., 2003). CHOP increases the expression of growth and arrest DNA damage 34 (GADD34; also known as PPP1R15A), which forms a complex with protein phosphatase 1 to dephosphorylate eIF $2 \alpha$ forming a negative feedback loop that dampens the ISR (Novoa et al., 2001). The ISR, especially via PERK, is protective in multiple disorders of oligodendrocytes and myelin, and enhancement of the ISR by inactivating GADD34 or CHOP is known to protect oligodendrocytes in multiple mouse models of disease. (Clayton and Popko, 2016; Way and Popko, 2016). In addition, the ISR responds to inflammation and excitotoxicity, both of which are insults known to contribute to DWMI (Deng, 2010; Hetz et al., 2013). This ability of the ISR to respond to multiple stresses involved in DWMI along with the known protective role of the ISR in other white matter disorders positions the ISR as an intriguing potential player and novel therapeutic target in DWMI (Bueter et al., 2009).

In this study, we explored the role of the ISR in DWMI with the goal of better understanding the mechanism and potential therapeutic targets of DWMI. To study this, we have examined primary isolated OPCs exposed to hypoxia and used two hypoxic mouse models of DWMI, a well established model of mild chronic hypoxia $(\mathrm{MCH}$; Scafidi et al., 2009, 2014; Fancy et al., 2011; Yuen et al., 2014) and a new alternative model of severe acute hypoxia (SAH). We demonstrate that both in vitro and in vivo hypoxia increase the phosphorylation of eIF $2 \alpha$, without induction of downstream ISR components. Moreover, oligodendrocyte-specific genetic inhibition of the ISR via Perk deletion exacerbates in vitro hypoxic damage to differentiating OPCs but does not affect either MCH- or SAH-induced DWMI. Together, these results suggest that while neonatal hypoxia leads to increased phosphorylation of eIF $2 \alpha$, it does not activate a full ISR response and that PERK-mediated ISR activation does not likely play a major role in hypoxia-induced DWMI. In addition, the genetic enhancement of the ISR in mice exposed to $\mathrm{MCH}$ or SAH by inactivating GADD34 and CHOP did not provide increased protection, suggesting that the ISR is an unlikely therapeutic target for DWMI.

\section{Materials and Methods}

Animals. All animals were housed under pathogen-free conditions, and all animal procedures were approved by the Institutional Animal Care and Use Committees of the University of Chicago. All mice were on the C57BL/6 background, and, unless otherwise stated, male and female mice were used.

C57BL/6 mice were obtained from The Jackson Laboratory (catalog \#000664). Olig2-Cre mice were provided by Dr. David Rowitch (University of Cambridge, Cambridge, UK) (Schüller et al., 2008) and floxed Perk mice were provided by Dr. Douglas Cavener (Pennsylvania State University, University Park, PA) (Zhang et al., 2002). Olig2-Cre;Perk FL/FL (OL-Perk-null) and littermate control Perk FL/FL mice lacking Cre expression (OL-Perk-FL) mice were used for experiments. Recombination efficiency with Olig2-Cre mice is reported to be $>90 \%$ (Kucharova and Stallcup, 2015). To determine the recombination efficiency Olig2-Cre mice were crossed to a ROSA26-YFP reporter line (stock \#006148, The Jackson Laboratory). Brain tissue collected and stained for Olig2 and yellow fluorescent protein (YFP) exhibited $79.6 \pm 11.6 \%$ of Olig $2^{+}$cells that were also $\mathrm{YFP}^{+}$(data not shown).

Gadd34-null mice were provided by Dr. David Ron (University of Cambridge, Cambridge, UK), and Chop-null mice (stock \#005530, The Jackson Laboratory) have been previously described and were bred inhouse (Zinszner et al., 1998; Novoa et al., 2001).

OPC isolation and culture. OPCs were isolated from postnatal day 5 (P5) to P7 mouse brains following the immunopanning protocol described by Barres et al. (1992) and subsequently modified and described previously (Dugas and Emery, 2013a; Emery and Dugas, 2013; Way et al., 2015). Cells were maintained as OPCs or differentiated into mature oligodendrocytes in media as previously described under control conditions as previously described (Dugas and Emery, 2013b; Emery and Dugas, 2013; Way et al., 2015). Wild-type (WT) OPCs were generated from WT mice while Perk knock-out (KO) OPCs were generated from OL-Perk-null mice.

Propidium iodide survival assay. Isolated OPCs were plated onto glass coverslips in proliferation media, and after $24 \mathrm{~h}$ of recovery cells were transferred to differentiation media with $500 \mathrm{ng} / \mathrm{ml}$ tunicamycin (catalog \#T7765, Sigma-Aldrich) for $24 \mathrm{~h}$. Following tunicamycin treatment, cells were stained with propidium iodide (catalog \#P4170, Sigma-Aldrich) to label dead cells and with fluorescein acetate (catalog \#F7378, SigmaAldrich) to label living cells. Three coverslips were counted per group, and the percentage of survival was presented.

In vitro hypoxia. For in vitro hypoxia experiments, OPCs isolated from P5-P7 mouse brains were transferred from control proliferation media to identical proliferation media that was deoxygenated under $100 \%$ nitrogen flow and then equilibrated to $0.1 \% \mathrm{O}_{2}$ for at least $2 \mathrm{~h}$ in a ProOx C21 carbon dioxide and oxygen controller (BioSpherix). Cells were then cultured at $0.1 \% \mathrm{O}_{2}$ and $10 \% \mathrm{CO}_{2}$ for various time periods based on the experiment.

Immunocytochemistry and cell counts. Immediately following $48 \mathrm{~h}$ of differentiation in either $0.1 \% \mathrm{O}_{2}$ or normoxia, cells were fixed with icecold $4 \%$ paraformaldehyde for $15 \mathrm{~min}$ at room temperature, washed with PBS, dried, and stored at $-80^{\circ} \mathrm{C}$.

Cells were blocked with 10\% FCS/0.3\% Triton in PBS and then incubated overnight in primary antibody in blocking solution. Cells were then washed with PBS and incubated with Alexa Fluor-conjugated secondary antibodies and mounted with Vectashield with DAPI mounting medium. The following primary antibodies were used: 1:250 myelin basic protein (MBP; catalog \#808402, BioLegend; RRID: AB_2314771) and 1:250 Olig2 (catalog \#MABN50, Millipore; RRID: AB_10807410).

Stained cells were imaged with an Olympus IX81 Inverted Microscope with a Hamamatsu Orca Flash 4.0 Camera. Five nonoverlapping fields of view were taken with a $20 \times$ objective, and the percentage of Olig ${ }^{+}$cells that were also $\mathrm{MBP}^{+}$were counted.

In vivo MCH and SAH models of DWMI. MCH is a well described model of DWMI (Scafidi et al., 2009, 2014; Fancy et al., 2011; Yuen et al., 2014). Mouse pups, both male and female, were genotyped and fostered to lactating $\mathrm{CD} 1$ dams at $\mathrm{P} 2$ and designated for either $\mathrm{MCH}$ or room air (RA) control. Fostering is required for this protocol since C57BL/6 dams do not care for their litters under hypoxic conditions (Scafidi et al., 2009, 2014). At P3, pups assigned to MCH were placed into a BioSpherix glove box maintained at $10 \pm 0.5 \% \mathrm{O}_{2}$ by displacement with nitrogen and controlled by a ProOx 360 oxygen controller from BioSpherix. Pups were exposed to $\mathrm{MCH}$ for $8 \mathrm{~d}$ from $\mathrm{P} 3$ to $\mathrm{P} 11$, after which they were returned to room air until the end of the experiment. Room air control mice were also fostered to $\mathrm{CD} 1$ dams and continued to breath room air for the duration of the experiment.

To our knowledge, SAH as a model of DWMI has not been previously described. Male and female mouse pups were fostered to lactating CD1 dams at P2 and designated for either SAH or RA control. Fostering was determined to be necessary experimentally. At P3, pups with acute severe hypoxia were placed into a BioSpherix glove box that was maintained at $7 \pm 0.5 \% \mathrm{O}_{2}$ by displacement with nitrogen under the control of a ProOx 360 oxygen controller from BioSpherix. Pups were exposed to SAH for 
$24 \mathrm{~h}$ from P3 to P4; after that, they were returned to room air until the end of the experiment. The duration of SAH was determined experimentally and was the maximum duration that lactating CD1 foster females could tolerate. Control mice breathing RA were also fostered to lactating CD1 dams and continued breathing room air for the duration of the experiment.

Total protein and RNA isolation. Protein was isolated from cells and snap frozen half-brain or frontal cortex rostral to the hippocampus using RIPA lysis buffer (catalog \#R0278, Sigma-Aldrich) supplemented with protease inhibitor pills (cOmplete Mini Protease Inhibitor Cocktail, catalog \#11836170001, Roche), Phosphatase Inhibitor Cocktail 2 (catalog \#P2850, Sigma-Aldrich), Phosphatase Inhibitor Cocktail 3 (catalog \#P5726, SigmaAldrich), and $17.5 \mathrm{~mm} \beta$-glycerophosphate (catalog \#G9422, SigmaAldrich). Protein lysates were then clarified by centrifugation and stored at $-80^{\circ} \mathrm{C}$. Protein concentration was determined using a BCA Protein Assay Kit (catalog \#23255, Thermo Fisher Scientific). The region of the frontal cortex rostral to the hippocampus was isolated to study myelin protein levels in subcortical white matter that is susceptible to hypoxia-induced DWMI (Ment et al., 1998; Fagel et al., 2006; Jablonska et al., 2012; Scafidi et al., 2014; Yuen et al., 2014).

RNA was isolated from cells and snap-frozen half-brain as previously described (Way et al., 2015). RNA quality was confirmed on a model 2100 Bioanalyzer using a model 6000 Nano Kit (catalog \#5067-1511, Agilent Technologies) according to the manufacturer instructions. Only samples with an RNA integrity number $>7$ were used.

Western blot. Western blot analysis was performed as previously described (Way et al., 2015). The following primary antibodies were used: 1:500 p-eIF2 $\alpha$ (catalog \#AB32157, Abcam; RRID: AB_732117), 1:1000 eIF2 $\alpha$ (catalog \#9722S, Cell Signaling Technology; RRID: AB_1069509), 1:250 ATF4 (catalog \#ARP37017, Aviva Systems Biology; RRID: AB_593104), 1:250 myelin-associated glycoprotein (MAG; catalog \#346200, Thermo Fisher Scientific; RRID: AB_2533179), 1:250 2',3'-cyclicnucleotide $3^{\prime}$-phosphodiesterase (CNP; catalog \#836401, BioLegend; RRID: AB_510037), 1:1000 MBP (catalog \#808402, BioLegend; RRID: AB_2314771), 1:500 ATF6 (catalog \#BAM-73-505, Cosmo Bio; RRID: AB_10709801), 1:500 pPKR (catalog \#PA5-37704, Thermo Fisher Scientific; RRID: AB_254312), 1:500 PKR (catalog \#AB45427, Abcam; RRID: AB_777309), and 1:2000 actin (catalog \#A2066, SigmaAldrich; RRID: AB_476693). For the presentation of representative blots, bands from the same membrane are presented in the same window and are separated by a solid line when cropped. Bands that are presented in separate windows are from different membranes.

Quantitative real-time PCR and real-time PCR Xbp1 splicing assay. Quantitative real-time PCR was performed as previously described (Way et al., 2015). Results were analyzed using the $\Delta \Delta \mathrm{C}(\mathrm{t})$ method with the Pfaffl correction for primer set-specific PCR efficiency (Pfaffl, 2001) on the Bio-Rad CFX Manager software. RPL13A was used as the reference gene. The efficiency of each primer set was determined by running reactions with known dilutions of cDNA at $60^{\circ} \mathrm{C}$ followed by calculation on the Bio-Rad CFX Manager software. Primers and efficiencies can be found in Table 1).

A real-time PCR Xbp1 splicing assay was performed as previously described (Hussien et al., 2015). The primers for Xbp1 splicing assay were as follows: forward primer, 5' - A AAC AGA GTA GCA GCG CAG ACT GC- ${ }^{\prime}$; and reverse primer, $5^{\prime}$-TC CTT CTG GGT AGA CCT CTG GGA G- $3^{\prime}$. Unspliced $X p b 1$ product size is $480 \mathrm{bp}$ and spliced $\mathrm{Xbp} 1$ product size is $454 \mathrm{bp}$. Positive and negative controls for the assay were from 3T3 cells treated with thapsigargin or untreated, respectively.

Immunohistochemistry and cell counts. Immunohistochemistry and cell counts were performed as previously described (Way et al., 2015). The following primary antibodies were used: 1:250 MBP (catalog \#808402, BioLegend), 1:50 Olig2 (catalog \#AB9610, Millipore), and 1:50 CC1 (catalog \#OP80, Calbiochem), 1:100 Sox10 (catalog \#AF2864, R\&D Systems), 1:100 p-eIF2 $\alpha$ (catalog \#AB32157, Abcam; RRID: AB_732117), 1:500 ATF4 (catalog \#ARP37017, Aviva Systems Biology; RRID: AB_593104), 1:250 CHOP (catalog \#MA1-250, Thermo Fisher Scientific; RRID: AB_2292611), 1:100 ATF6 (catalog \#BAM-73-505, Cosmo Bio; RRID: AB_10709801). Images were acquired on an Olympus IX81 Inverted Microscope with a Hamamatsu Orca Flash 4.0 Camera. Images were ac-

\section{Table 1. Primer sequences and PCR efficiencies}

\begin{tabular}{|c|c|c|}
\hline $\begin{array}{l}\text { Gene of } \\
\text { interest }\end{array}$ & Primers & $\begin{array}{l}\text { PCR efficiency } \\
\text { at } 60^{\circ} \mathrm{C}\end{array}$ \\
\hline Bip & $\begin{array}{l}\text { Fwd: 5'-ACT CCG GCG TGA GGT AGA AA-3' } \\
\text { Rev: 5'-AGA GCG GAA CAG GTC CAT GT-3' }\end{array}$ & $102.0 \%$ \\
\hline Atf4 & $\begin{array}{l}\text { Fwd: 5'-TGG ATG ATG GCT TGG CCA GTG-3' } \\
\text { Rev: 5'-GAG CTC ATC TGG CAT GGT TTC-3' }\end{array}$ & $114.0 \%$ \\
\hline Chop & $\begin{array}{l}\text { Fwd: 5' -CCA CCA CAC CTG AAA GCA GAA-3' } \\
\text { Rev: 5'-AGG TGC CCCC CAA TTT CAT CT-3' }\end{array}$ & $106.8 \%$ \\
\hline Gadd34 & $\begin{array}{l}\text { Fwd: } 5^{\prime}-\text {-CC TCC AAC TCT CCT TCT TCA G-3' } \\
\text { Rev: 5'-CAG CCT CAG CAT TCC GAC AA-3' }\end{array}$ & $87.4 \%$ \\
\hline$M b p$ & $\begin{array}{l}\text { Fwd: 5'-GCT CCC TGC CCC AGA AGT-3' } \\
\text { Rev: 5'-TGT CAC AAT GTT CTT GAA GAA ATG G-3' }\end{array}$ & $102.7 \%$ \\
\hline Plp & $\begin{array}{l}\text { Fwd: 5'-CAC TTA CAA CTT CGC CGT CCT-3' } \\
\text { Rev: 5'-GGG AGT TTC TAT GGG AGC TCA GA-3' }\end{array}$ & $115.8 \%$ \\
\hline Mag & $\begin{array}{l}\text { Fwd: 5'-CTG CTC TGT GGG GCT GAC AG-3' } \\
\text { Rev:5'-AGG TAC AGG CTC TTG GCA ACT G-3' }\end{array}$ & $109.5 \%$ \\
\hline Rpl13a & $\begin{array}{l}\text { Fwd: 5'-TTC TCC TCC AGA GTG GCT GT-3' } \\
\text { Rev:5'-GGC TGA AGC CTA CCA GAA AG-3' }\end{array}$ & $98.9 \%$ \\
\hline
\end{tabular}

Fwd, Forward; Rev, reverse. List of primers used for quantitative real-time PCR analysis. Efficiency was determined by running standard dilutions at $60^{\circ} \mathrm{C}$ and calculated on Bio-Rad CFX Manager Software

quired from the subcortical white matter at the level of the corpus callosum and cingulum in the frontal cortex rostral to the hippocampus and of anatomically similar sections. Approximately $100 \mathrm{Olig} 2^{+}$cells were counted per mouse to calculate the percentage of $\mathrm{CC}^{+} / \mathrm{Olig}{ }^{+}$cells.

Statistics. Data are presented as mean \pm SEM unless otherwise noted. Multiple comparisons were made using ANOVA with Tukey's post-test. Comparisons of two data points were made using a two-sided unpaired $t$ test. A $p$ value of $<0.05$ was considered significant, and all statistical analysis was run with GraphPad Prism software.

\section{Results \\ Hypoxic activation of the ISR in primary OPCs is PERK dependent}

It has been shown in mouse embryonic fibroblasts that in vitro hypoxia activates the ISR, as indicated by increased phosphorylation of eIF2 $\alpha$ (Koumenis et al., 2007; Liu et al., 2010). Nevertheless, it is not known whether in vitro hypoxia increases eIF $2 \alpha$ phosphorylation in OPCs. In addition, the kinase PERK has been shown to be responsible for eIF $2 \alpha$ phosphorylation in response to hypoxia, since Perk knock-out mouse embryonic fibroblasts have decreased the phosphorylation of eIF $2 \alpha$ in response to hypoxia compared with WT mouse embryonic fibroblasts (Koumenis et al., 2002; Blais et al., 2006; Liu et al., 2010). To investigate whether in vitro hypoxia increases the phosphorylation of eIF $2 \alpha$ and whether PERK plays a role in this activation, we generated WT and Perk KO OPCs. We first confirmed the decrease in PERK protein levels in Perk KO OPCs (Fig. 1A) and that Perk KO OPCs were more susceptible to the ER stressor tunicamycin (Fig. $1 B, C)$. We then exposed primary isolated mouse OPCs to $0.1 \%$ $\mathrm{O}_{2}$ for 0,3 , and $6 \mathrm{~h}$. Following hypoxic exposure, the levels of p-eIF $2 \alpha$ were measured. We found that the exposure of WT OPCs to 3 and 6 h of hypoxia resulted in significantly increased levels of phosphorylated eIF $2 \alpha$ compared with WT OPCs exposed to 0 h hypoxia (Fig. $1 D, E$ ). Moreover, when compared with time-matched Perk KO OPCs, we found that WT OPCs had significantly higher p-eIF2 $\alpha$ levels at 3 and $6 \mathrm{~h}$ (Fig. $1 D, E$ ). This showed that hypoxia increases p-eIF $2 \alpha$ levels in isolated OPCs and that PERK plays a role in these increased levels of p-eIF $2 \alpha$. Nevertheless, Perk KO OPCs after 6 h of hypoxia still had significantly higher levels of p-eIF2 $\alpha$ compared with control Perk KO OPCs (Fig. $1 D, E$ ). This suggests that PERK is not the sole kinase responsible for phosphorylating eIF $2 \alpha$ in response to hypoxia. 
A

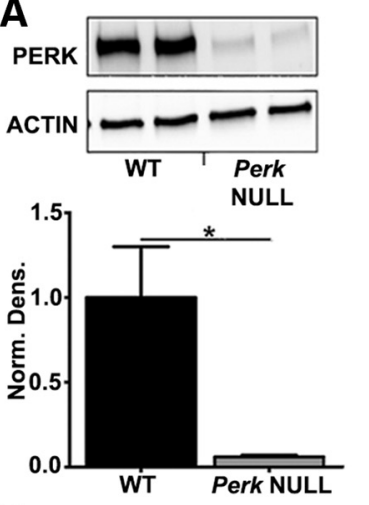

D
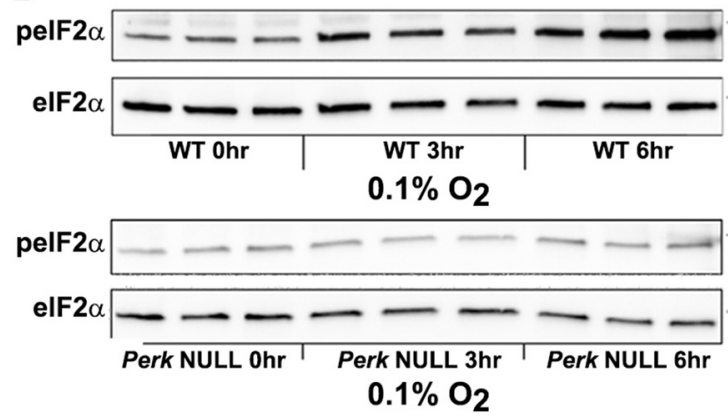

$\mathbf{F}$

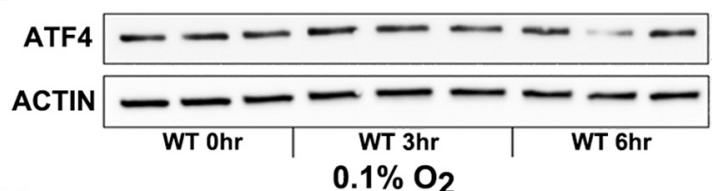

H

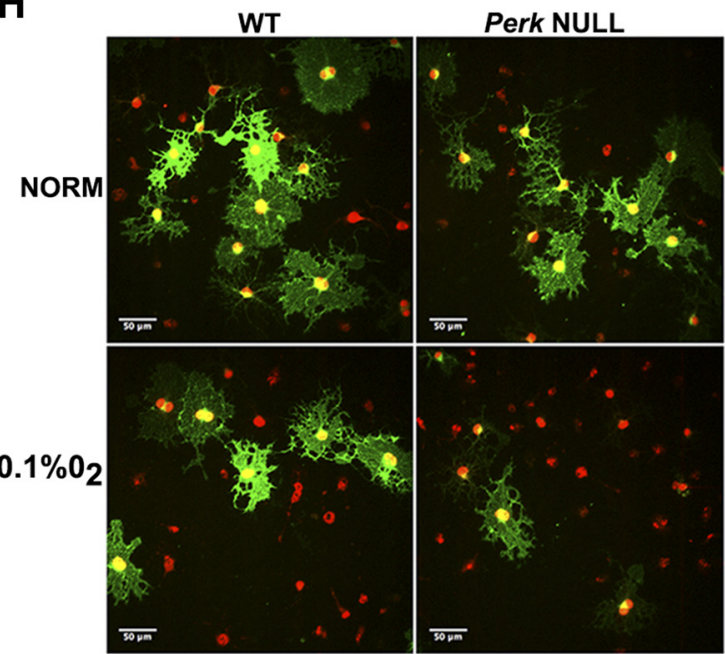

B

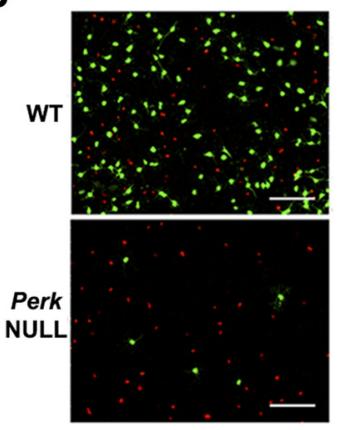

C
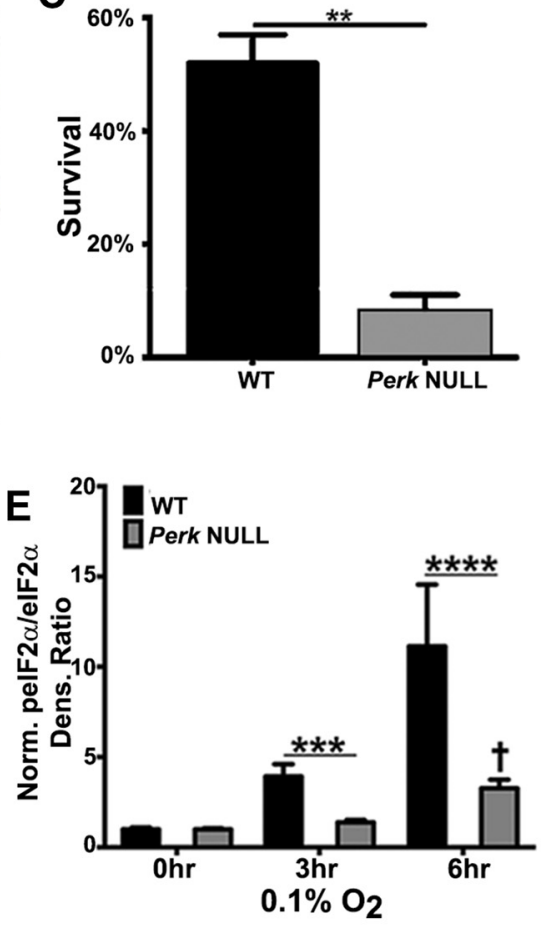

G

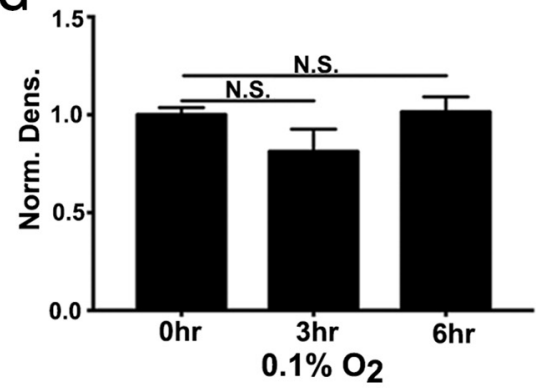

I

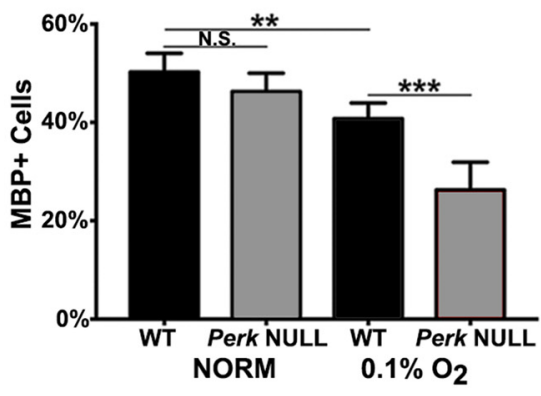

Figure 1. PERK signaling protects oligodendrocytes from hypoxia in vitro.A, Representative blot and quantification of PERK protein levels in WT and Perk KO OPCs. Quantification represents three individual OPC isolations with ${ }^{*} p<0.05$ by unpaired two-tailed $t$ test. $\boldsymbol{B}$, Representative images of WT and Perk KO OPCs exposed to $500 \mathrm{ng} / \mathrm{ml}$ ER stressor tunicamycin for $24 \mathrm{~h}$ and stained with fluorescein diacetate (green) and propidium iodide (red) to label living and dead cells, respectively. C, Quantification of the percentage of survival of WT and Perk KO OPCs exposed to $500 \mathrm{ng} / \mathrm{ml}$ tunicamycin for $24 \mathrm{~h}$ with ${ }^{*} p<0.05$ by unpaired two-tailed $t$ test. $\boldsymbol{D}$, Representative $\mathrm{p}$-elF $2 \alpha$ and elF $2 \alpha$ blots of WT and Perk KO OPCs exposed to 0,3 , and $6 \mathrm{~h}$ of $0.1 \% 02$. E, Quantification of $p$-elF $2 \alpha$ and elF $2 \alpha$ blots, with data presented as the $\mathrm{p}$-elF $2 \alpha / \mathrm{elF} 2 \alpha$ ratio normalized to genotype-matched $0 \mathrm{~h} 0.1 \% \mathrm{O}_{2}$ control. Data represent three individual $\mathrm{OPC}$ isolations each with three replicates. ${ }^{* * *} p<0.005$ and ${ }^{* * * *} p<0.0001$ vs time-matched WT controls by paired $t$ test. $\nmid p<0.05 \mathrm{vs} 0 \mathrm{~h}$ Perk KO control by ANOVA. F, Representative images of ATF 4 blots of WT OPCs exposed to $0.1 \%$ $\mathrm{O}_{2}$ for 0,3 , and $6 \mathrm{~h}$. G, Quantification of ATF4 protein levels in $0.1 \% 0$, exposed WT OPCs. $\boldsymbol{H}$, Representative images of WT and Perk KO OPCs differentiated for $48 \mathrm{~h}$ under normoxia (NORM) or $0.1 \%$ $0_{2}$ and stained for the mature oligodendrocyte marker MBP (green) and the pan-oligodendrocyte lineage cell marker Olig2 (red). $I$, Quantification of the percentage of MBP ${ }^{+}$cells in WT and Perk KO cultures exposed to $0.1 \% 0_{2}$ and NORM. Data represent four repeat experiments with ${ }^{* *} p<0.01$ by ANOVA with Tukey's post-test. All data are presented as the mean \pm SEM. Scale bars, $50 \mu \mathrm{m}$. Norm. Dens., Normalized density. 
A

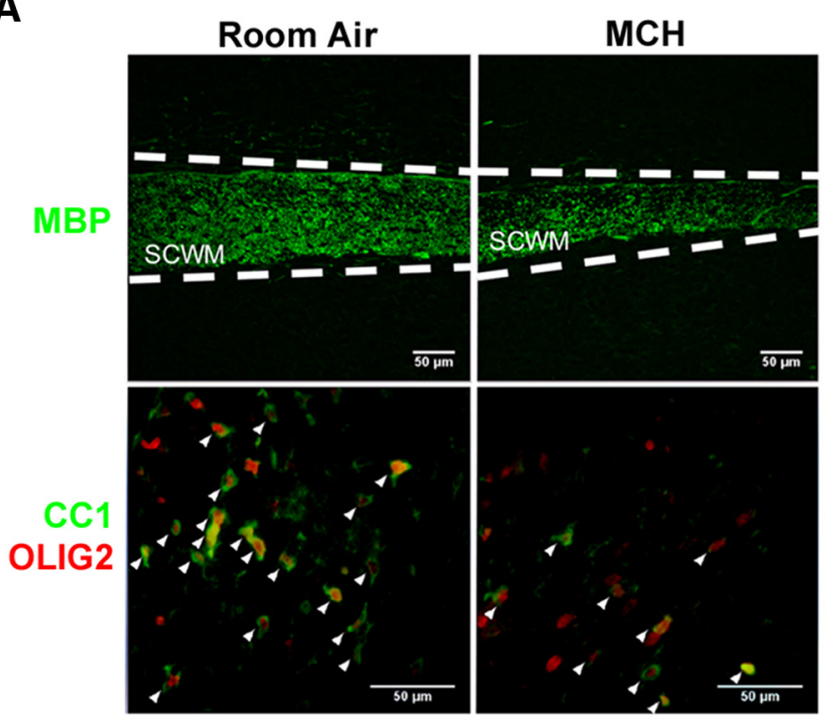

B

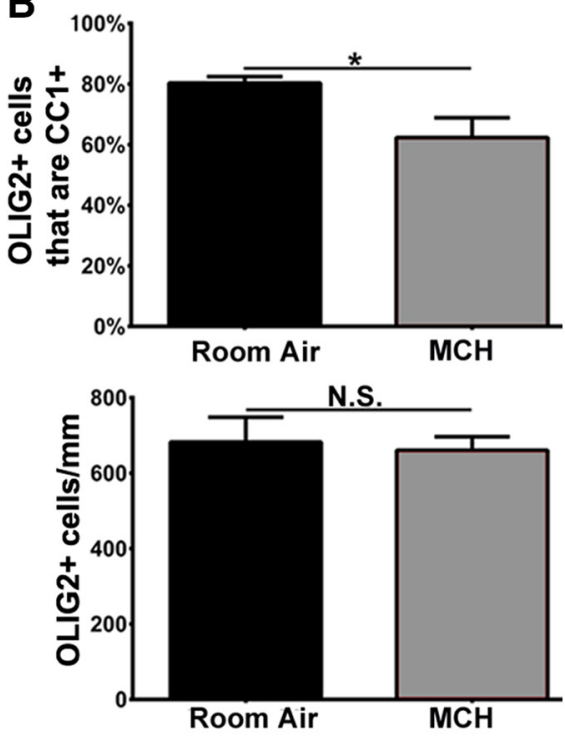

C

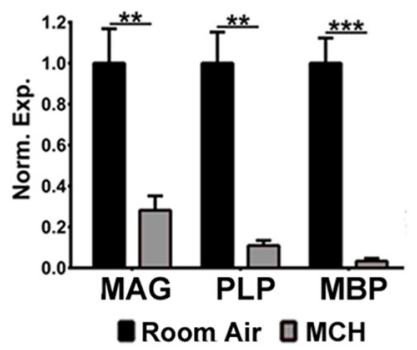

D

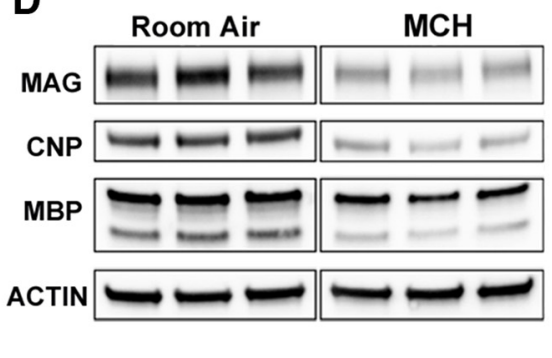

E

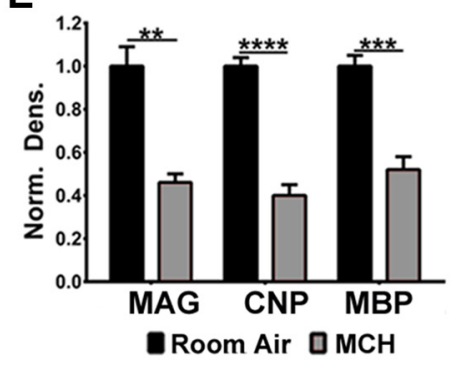

Figure 2. Mild chronic hypoxia causes diffuse white matter injury. A, Top panels are representative images of MBP-stained (green) subcortical white matter (SCWM) from P18 mice exposed to MCH or RA control. Bottom panels are representative images of mature $\mathrm{CC}^{+}{ }^{+}$(green) oligodendrocytes and 0lig2 ${ }^{+}$(red) oligodendrocyte lineage cells from P18 mice exposed to MCH or RA. $B$, Quantification of the percentage of Olig2 ${ }^{+}$oligodendrocyte lineage cells that are $\mathrm{CC}^{+}$mature oligodendrocytes and density of 0 lig2 ${ }^{+}$oligodendrocyte lineage cells in P18 $\mathrm{MCH}$ - and RA-exposed mice. Data represent $N \geq 3$ mice/group with ${ }^{*} p<0.05$ by unpaired two-tailed $t$ test. $C$, Analysis of myelin-enriched mRNA Mag, Plp, and Mbp in P11 mice exposed to MCH or RA. Data represent $N \geq 3$ with ${ }^{* *} p<0.005$ and ${ }^{* * *} p<0.0001$. D, Representative blots of myelin-enriched proteins MAG, CNP, and MBP from P18 mice exposed to MCH or RA. E, Quantification of MAG, CNP, and MBP protein levels from P18 mice exposed to MCH or RA. Data represent $N \geq 3$ mice/group with ${ }^{* *} p<0.01$, ${ }^{* * *} p<0.005$, and ${ }^{* * * *} p<0.0001$ by unpaired two-tailed $t$ test. All data are presented as the mean \pm SEM. Scale bar, $50 \mu \mathrm{m}$. Norm. Exp., Normalized expression; Norm. Dens., normalized density.

We also examined the levels of ATF4 protein in WT OPCs exposed to $0.1 \% \mathrm{O}_{2}$ and found that there is no significant difference in ATF4 protein levels (Fig. $1 F, G$ ).

To determine whether the diminished capacity of Perk KO OPCs to phosphorylate eIF $2 \alpha$ in response to hypoxia results in an enhanced susceptibility to hypoxia, we exposed differentiating WT and Perk KO OPCs to $0.1 \%$ oxygen for $48 \mathrm{~h}$. We found that, as previously reported (Yuen et al., 2014), hypoxia decreased the percentage of $\mathrm{MBP}^{+}$mature oligodendrocytes compared with cells differentiated under normoxic conditions (Fig. $1 H, I$ ). In addition, we discovered that Perk KO cells were more vulnerable to in vitro hypoxia and displayed significantly fewer $\mathrm{MBP}^{+}$cells compared with WT cells exposed to hypoxia (Fig. $1 \mathrm{H}, I$ ). This demonstrates that in WT oligodendrocyte lineage cells, PERK activation provides protection against hypoxia since the lack of PERK leads to increased loss of $\mathrm{MBP}^{+}$cells in hypoxia-exposed cultures.

\section{MCH causes DWMI in neonatal mice}

Brain injury from chronic hypoxia caused by immature lung development has been modeled by $\mathrm{MCH}$ in neonatal mice (Scafidi et al., 2009). We first examined the brains of $\mathrm{MCH}$-exposed mice to validate that $\mathrm{MCH}$ causes DWMI. MCH caused decreased
MBP immunostaining and decreased numbers of mature $\mathrm{CC}^{+}$ oligodendrocytes in the subcortical white matter (Fig. 2A,B). Importantly, the total number of oligodendrocyte lineage cells, marked by oligodendrocyte transcription factor OLIG-2, was not significantly altered, suggesting that $\mathrm{MCH}$ caused decreased maturation of OPCs into mature $\mathrm{CCl}^{+}$oligodendrocytes (Fig. $2 B$ ). In addition, $\mathrm{MCH}$ led to decreased levels of the mature myelinspecific proteins and/or mRNA MAG, CNP, myelin proteolipid protein (PLP), and MBP (Fig. 2C-E). This confirms that, as previously described, $\mathrm{MCH}$ is a valid model of DWMI.

\section{MCH increases phosphorylation of eIF2 $\alpha$ in brain without} increasing downstream ISR components or activating other arms of the UPR

As shown in vitro, hypoxia increases the phosphorylation of eIF $2 \alpha$, which is indicative of the activation of the ISR. To determine whether in vivo $\mathrm{MCH}$ activates the ISR in neonatal mouse brains, we collected brain tissue at various durations of $\mathrm{MCH}$ exposure. We found that at 4 and $6 \mathrm{~d}$ of MCH, levels of p-eIF $2 \alpha$ in total brain lysates were significantly higher compared with agematched room air controls (Fig. $3 A, B$ ). Nevertheless, there was no detectable increase in the percentage of $\mathrm{p}$-eIF $2 \alpha^{+} /$Sox $10^{+}$ oligodendrocyte lineage cells in sections from pups exposed to $4 \mathrm{~d}$ 
A

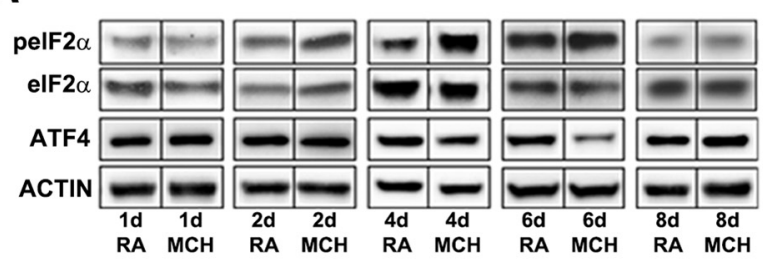

D

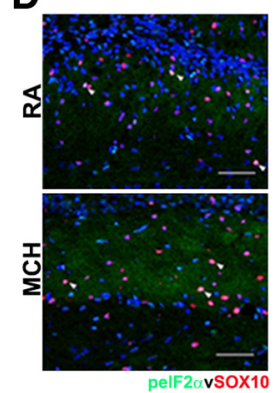

E

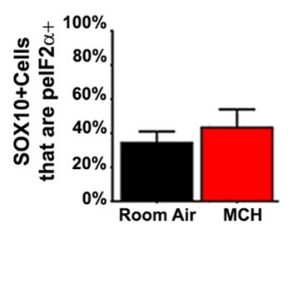

F
B

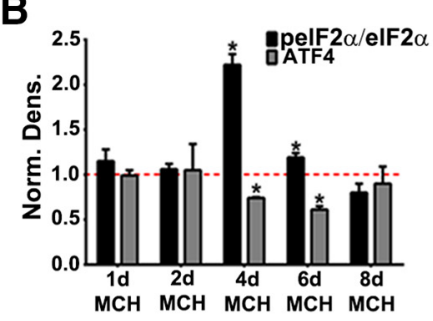

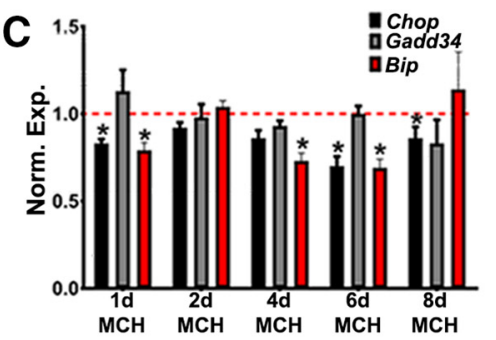

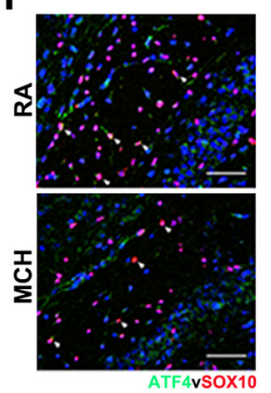

G

H

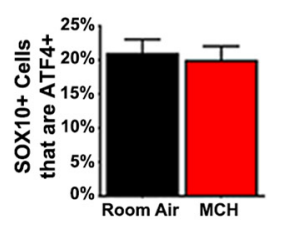

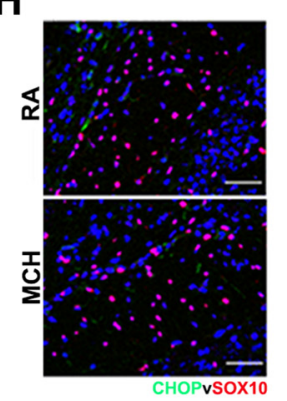

I

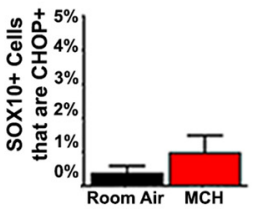

Figure 3. Mild chronic hypoxia increases the phosphorylation of elF $2 \alpha$ in the brain but decreases ATF4 protein levels and does not induce downstream ISR components CHOP and GADD34. $\boldsymbol{A}$, Representative p-elF2 $\alpha$, elF2 $\alpha$, and ATF4 blots from mice exposed to 1,2, 4, 6, or $8 \mathrm{~d}$ of MCH or RA control. $\boldsymbol{B}$, Quantification of p-elF2 $\alpha$, elF2 $\alpha$, and ATF4 protein levels. Data are presented as the p-elF2 $\alpha /$ elF $2 \alpha$ ratio normalized to time-matched RA-exposed control mice. C, Expression of Chop, Gadd34, and Bip mRNA levels normalized to time-matched RA-exposed controls. $\boldsymbol{D}$, Representative image of P7 mouse brain exposed to $4 \mathrm{~d}$ of MCH and RA stained with Sox 10, a pan-oligodendrocyte lineage cell marker, and p-elF $2 \alpha$. Scale bar, $100 \mu \mathrm{m}$. $\boldsymbol{E}$, Quantification of Sox $10^{+}$cells that are p-elF $2 \alpha^{+}$. F, Representative images of P7 mouse brain exposed to MCH and RA for $4 \mathrm{~d}$ and stained for Sox 10 and ATF4. Scale bar, $50 \mu \mathrm{m} . \mathbf{G}$, Quantification of Sox $10{ }^{+}$cells that are p-elF $2 \alpha^{+}$.H, Representative images of Sox 10 and CHOP staining from P7 mouse brain exposed to $4 \mathrm{~d}$ of MCH and RA. Scale bar, $50 \mu \mathrm{m} . \mathbf{I}$, Quantification of Sox $10^{+}$cells that are CHOP ${ }^{+}$. All data are presented as the mean \pm SEM for $N \geq 3$ mice/group with ${ }^{*} p<0.05$ compared with time-matched controls (red dashed line) by unpaired two-tailed $t$ test.

of $\mathrm{MCH}$ versus RA controls (Fig. 3D,E). Interestingly, the hypoxia-induced increase of p-eIF2 $\alpha$ (Fig. $3 A, B$ ) was not accompanied by an increase in protein levels of the downstream ISR transcription factor ATF4. Instead, ATF4 protein levels in total brain at 4 and $6 \mathrm{~d}$ of $\mathrm{MCH}$ were significantly decreased compared with age-matched room air controls (Fig. $3 A, B$ ). Consistent with the lack of an oligodendrocyte lineage-specific increase in $\mathrm{p}$ eIF2 $\alpha$ staining (Fig. $3 D, E$ ), there was no difference in the number of $\mathrm{ATF} 4^{+} / \mathrm{Sox} 10^{+}$cells in $\mathrm{MCH}$ versus control brains (Fig. $3 F, G)$. We also saw no evidence of increased expression of the downstream ISR factors Chop, Gadd34, or Bip (Fig. 3C), and no evidence of increased $\mathrm{CHOP}^{+} / \mathrm{Sox} 10^{+}$cells in $\mathrm{MCH}$ brains (Fig. $3 H, I)$. Our results suggest that while increased phosphorylation of eIF $2 \alpha$ occurs in the brain in response to $\mathrm{MCH}$, this increase does not result in the activation of downstream aspects of the ISR.

As mentioned, the PERK pathway plays a role in both the ISR and the UPR, and phosphorylation of eIF2a occurs in both stress response pathways. Consequently, when studying the PERK pathway, it is important to determine whether increased p-eIF2a is occurring with, or independent of, activation of the other two UPR sensors IRE1 and ATF6. To determine whether phosphorylation of eIF $2 \alpha$ in $\mathrm{MCH}$ is occurring in concert with the activation of the UPR or independently as a component of the ISR, we measured $X b p 1$ splicing in brains exposed to either $\mathrm{MCH}$ or RA control. $\mathrm{MCH}$ did not induce splicing of $\mathrm{Xbp1}$ at any time point examined, suggesting that the IRE1 arm of the UPR is not activated (Fig. 4A). Moreover, the levels of activated cleaved ATF6 were not significantly affected by $\mathrm{MCH}$ (Fig. $4 B, C$ ), and no increase in Sox $10^{+}$oligodendrocyte lineage cells with nuclear ATF6 staining was observed (Fig. 4D,E). These data suggest that phosphorylation of eIF2a by $\mathrm{MCH}$ is not associated with ER stress and activation of the unfolded protein response.

\section{Effects of genetic inhibition of the ISR on} MCH-induced DWMI

We next examined whether the PERK arm of the ISR protects oligodendrocytes and myelin from $\mathrm{MCH}$-induced DWMI, similar to what we observed in vitro (Fig. 1). To determine whether oligodendrocyte-specific deletion of Perk exacerbated $\mathrm{MCH}$ induced DWMI, we crossed Olig2/Cre and Perk ${ }^{\mathrm{FL} / \mathrm{FL}}$ mice to generate OL-Perk-FL controls and OL-Perk-null mice that were then exposed to MCH. Olig2/Cre mice express Cre in all cells of the oligodendrocyte lineage; therefore, Perk is deleted specifically from oligodendrocyte lineage cells generating OL-Perk-null mice.

We first determined that oligodendrocyte-specific deletion of Perk has no effect on developmental myelination. The expression of myelin-specific proteins MAG and MBP was not significantly different between untreated OL-Perk-FL and OL-Perk-null mice (Fig. 5A,B). Moreover, oligodendrocyte lineage cell-specific deletion of Perk had no effect on the number of mature $\mathrm{CC} 1^{+}$ oligodendrocytes (Fig. 5C,D). These data are consistent with our previous demonstration that PERK activity is not required for oligodendrocyte development or myelination (Hussien et al., 2014).

We next found that, compared with OL-Perk-FL mice exposed to $\mathrm{MCH}, \mathrm{OL}-$ Perk-null mice exposed to $\mathrm{MCH}$ displayed no significant difference in expression levels of myelin-specific proteins MAG, CNP, and MBP by Western blot analysis (Fig. 6A, $B$ ), levels of MBP staining on tissue sections (Fig. $6 C$ ), or the percentage of mature oligodendrocytes stained with CC1 (Fig. 6C,D). In addition, oligodendrocyte-specific deletion of Perk had no effect on the increased levels of p-eIF2 $\alpha$ caused by MCH (Fig. 6E,F). These data suggest that PERK signaling within oligodendrocyte lineage cells does not play a protective role under mild chronic hypoxic stress in vivo. 
A

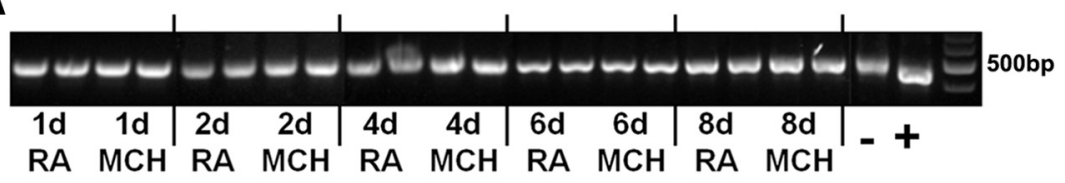

B
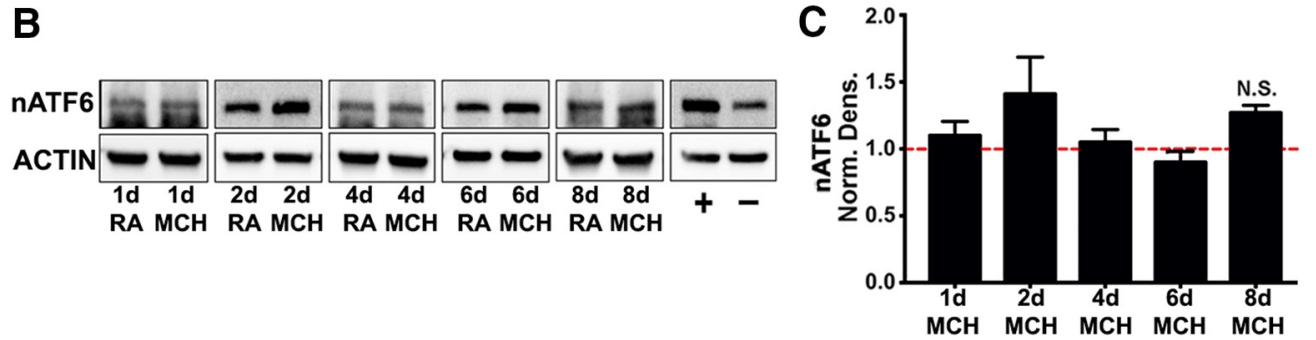

Doom Air

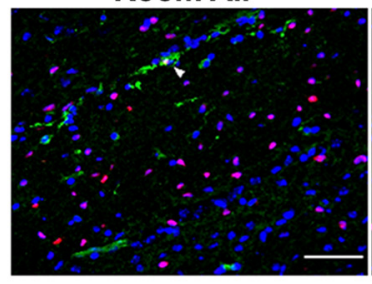

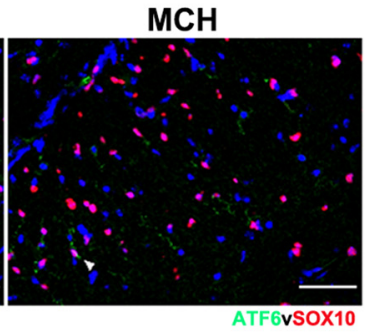

E

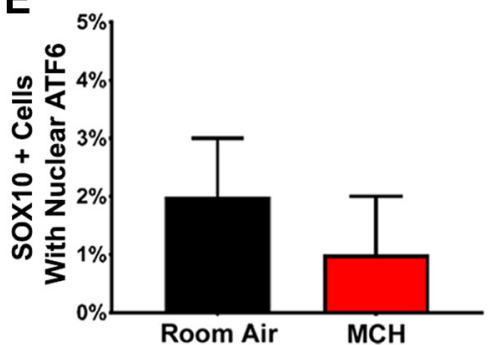

Figure 4. Mild chronic hypoxia does not activate the IRE-1 or ATF6 arms of the unfolded protein response. $A$, Representative Xbp1 PCR gel image of mice exposed to MCH or RA. Unspliced Xbp1 product size of $480 \mathrm{bp}$ and spliced Xbp 1 product size of $454 \mathrm{bp}$. Lines represent where images from different gels have been cropped and spliced together. B, Representative ATF6 blots from mice exposed to 1, 2, 4, 6, or $8 \mathrm{~d}$ of MCH or RA. C, Quantification of ATF6 protein levels normalized to time-matched RA-exposed controls. D, Representative images from P7 mice exposed to MCH for $4 \mathrm{~d}$ and stained with ATF6 versus the oligodendrocyte lineage marker Sox10. E, Quantification of the percentage of Sox $10^{+}$cells that are nuclear ATF ${ }^{+}$. All data are presented as the mean \pm SEM for $N \geq 3$ mice/group. Scale bar, $50 \mu \mathrm{m}$.

In addition to PERK, other eIF $2 \alpha$ kinases, including the eIF $2 \alpha$ kinase PKR (also called Eif2ak2) are activated by cytotoxic stress (Liu et al., 2010; Taniuchi et al., 2016). Therefore, we measured PKR activation by $\mathrm{MCH}$ and found that hypoxia exposure increased PKR phosphorylation in total brain lysate compared with room air controls (Fig. $6 G, H$ ). These results may explain the lack of effect caused by oligodendrocyte-specific excision of PERK.

Severe acute hypoxia is an alternative model of hypoxia-induced DWMI in neonatal mice

In addition to chronic hypoxic insults, the premature neonate is also exposed to brief episodes of severe hypoxia (Martin et al., 2011). Since oligodendrocyte-specific Perk ablation did not have a measurable effect on $\mathrm{MCH}$-induced DWMI, we examined whether the ISR plays a role in DWMI caused by severe acute hypoxia. To address this question, we determined whether $\mathrm{SAH}$ leads to DWMI in neonatal mice. Neonatal mice were exposed to $7 \pm 0.5 \% \mathrm{O}_{2}$ for $24 \mathrm{~h}$ from P3 to P4. Similar to the MCH model, the SAH model leads to decreased MBP staining in the subcortical white matter and decreased numbers of mature $\mathrm{CC}^{+}$oligodendrocytes with no change in the number of total OLIG $2^{+}$cells (Fig. $7 A, B$ ). Moreover, SAH-exposed pups exhibited decreased levels of the mature myelin proteins and/or mRNA of MAG, CNP, PLP, and MBP (Fig. 7C,E). These data establish that SAH is a valid model of DWMI in which we could examine the role of the ISR.

Severe acute hypoxia increases phosphorylation of eIF $2 \alpha$ in neonatal mouse brains without increasing downstream ISR components or activating other arms of the UPR

Having established SAH as a model of DWMI, we next examined whether SAH activates the ISR in the neonatal brain. Similar to
$\mathrm{MCH}, \mathrm{SAH}$ leads to increased phosphorylation of eIF2 $\alpha$ in whole-brain lysates from mice exposed to the hypoxic insult (Fig. $8 A, B)$. SAH increased p-eIF $2 \alpha$ levels within $12 \mathrm{~h}$, more rapidly than under conditions of mild hypoxic stress, suggesting that activation of the ISR is tuned to the severity of hypoxic insult. Phosphorylation of eIF $2 \alpha$ was also transient in $\mathrm{SAH}$, returning to baseline level by the end of the $24 \mathrm{~h}$ hypoxic exposure. Similar to $\mathrm{MCH}$, there was no significant increase in the percentage of p-eIF $2 \alpha^{+} /$Sox $10^{+}$oligodendrocyte lineage cells in the subcortical white matter of SAH-exposed pups (Fig. 8D,E). Moreover, SAH did not increase the levels of downstream ISR components. Like MCH, SAH caused a decrease in ATF4 protein levels (Fig. $8 A, B)$, which likely explains the subsequent lack of Chop, Gadd34, and Bip mRNA induction (Fig. 8C). There was also no difference in the number of ATF $4^{+} / \mathrm{Sox} 10^{+}$or $\mathrm{CHOP}^{+} / \mathrm{Sox} 10^{+}$ cells in SAH-exposed pups compared with controls (Fig. 8F-I). Together, these experiments suggest that the transcriptional response driven by ATF4 does not play a significant role in the response to $\mathrm{SAH}$.

SAH also did not induce the splicing of Xbp 1 at any time point, suggesting that the IRE 1 arm of the UPR is not activated by SAH (Fig. 9A). Moreover, levels of activated cleaved ATF6 were not significantly affected by any duration of SAH (Fig. $9 B, C$ ), and there was no measurable increase in the number of Sox $10^{+}$cells with nuclear ATF6 positivity (Fig. 9D,E). These data again suggest that phosphorylation of eIF2a by SAH is not associated with ER stress and activation of the unfolded protein response.

Effects of genetic inhibition of the ISR on SAH-induced DWMI

We next examined the effect that genetic manipulation of the ISR would have on SAH-induced DWMI. We exposed OL-Perk-null 
A

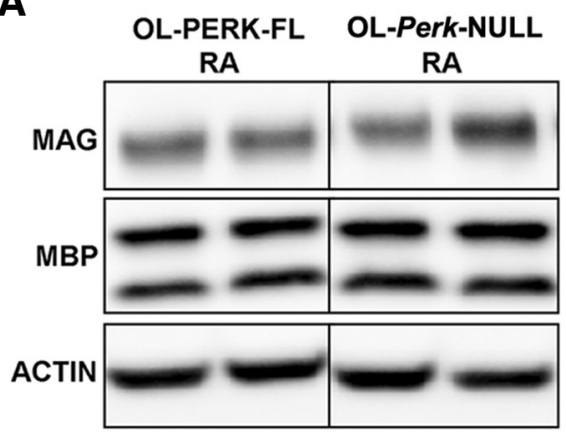

C

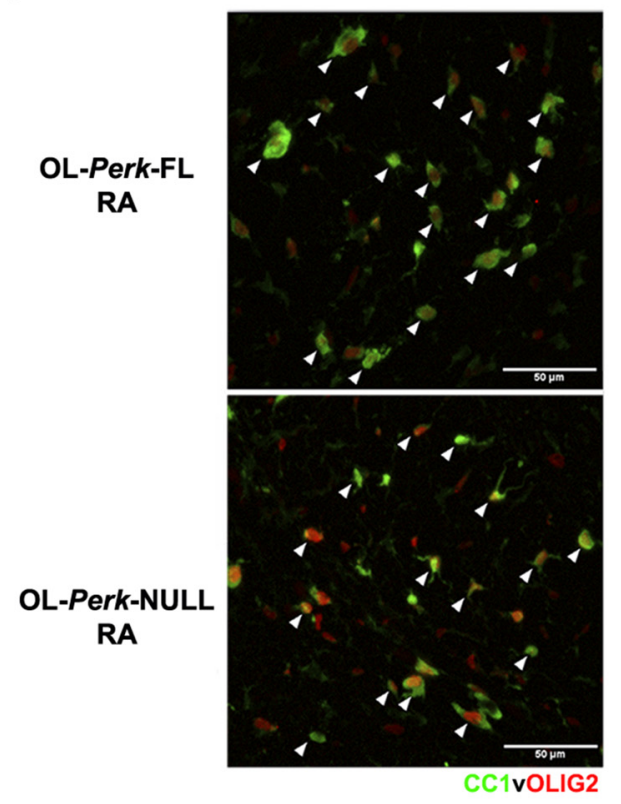

B

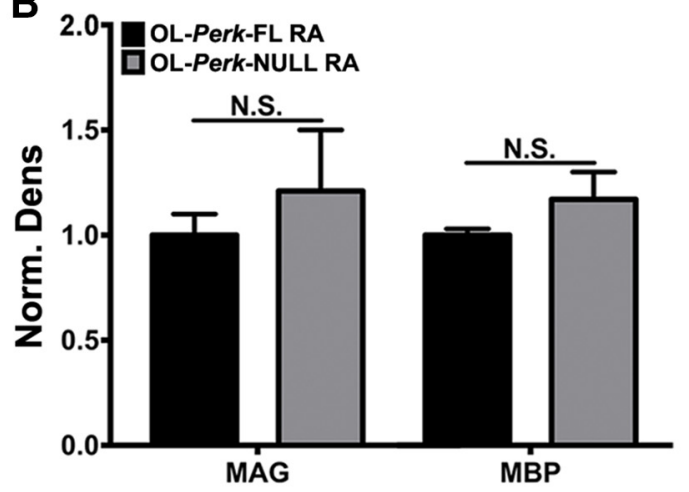

D
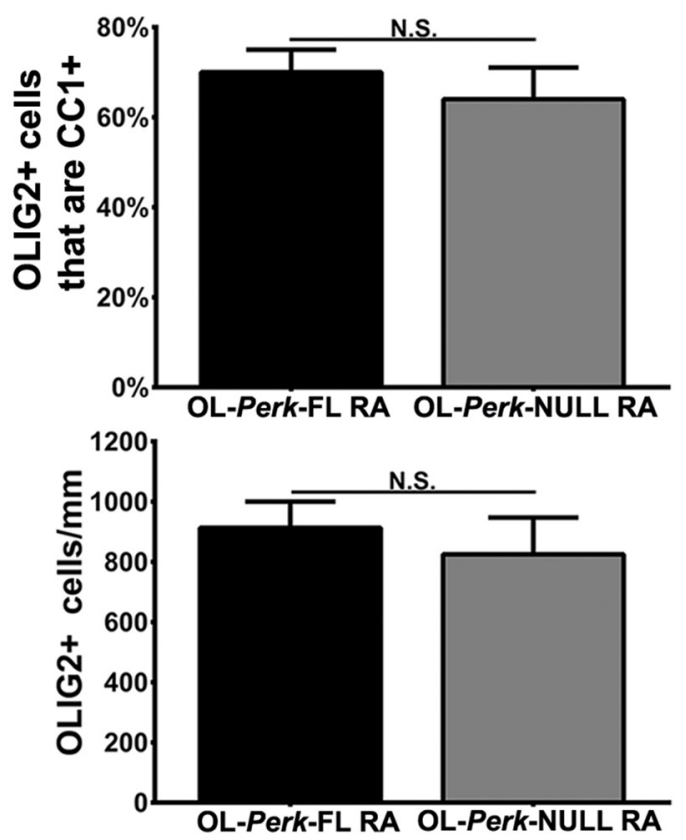

Figure 5. Excision of Perk from oligodendrocyte lineage cells has no effect on developmental myelination. A, Representative MAG and MBP blots from untreated P11 0L-Perk-FL and OL-Perk-null mice. $B$, Quantification of MAG and MBP protein levels. Data are presented as the mean $\pm S E M$ for $N \geq 3$ mice/group. C, Representative images of subcortical white matter from untreated P11 OL-Perk-FL and OL-Perk-null mice stained for OLIG2 (red) and CC1 (green). D, Quantification of the percentage of $\mathrm{CC}^{+} / \mathrm{OLIG2}^{+}$cells and $0 \mathrm{LIG}{ }^{+}$cell density. Data are presented as the mean \pm SEM for $N=3$ mice/group. Scale bar, $50 \mu \mathrm{m}$. Norm. Dens, Normoxia density.

and littermate OL-Perk-FL controls to SAH and examined myelin protein levels after $7 \mathrm{~d}$ of recovery at P11. There was no difference in the level of myelin-enriched proteins MAG, CNP, and MBP between OL-Perk-null and OL-Perk-FL pups exposed to SAH (Fig. 10A,B). These results were validated by MBP immunohistochemistry and cell counts of the percentage of mature $\mathrm{CC}^{+}$oligodendrocytes. No significant difference was found in the percentage of mature $\mathrm{CC}^{+}{ }^{+}$oligodendrocytes in OL-Perknull and OL-Perk-FL pups exposed to SAH (Fig. 10C,D). In addition, the levels of p-eIF $2 \alpha$ were not decreased in total brain lysate from OL-Perk-null animals (Fig. 10 E, F). These results suggest that, similar to $\mathrm{MCH}$-induced DWMI, the PERK arm of the ISR does not play a significant role in SAH-induced DWMI.

We also examined whether PKR activation might be responsible for the increase in p-eIF2 $\alpha$ levels in SAH-exposed brains in the absence of PERK. Similar to our MCH results, we found that the level of phosphorylated PKR was higher in total brain lysate from SAH-exposed pups compared with controls (Fig. 10G,H).
Effects of genetic enhancement of the ISR on MCH- and SAH-induced DWMI

Inhibition of Gadd34 has been shown to protect oligodendrocytes in mouse models of multiple sclerosis (Lin et al., 2008; Way et al., 2015). Therefore, we examined whether enhancing the ISR through global Gadd34 deletion protects oligodendrocytes and white matter from MCH- and SAH-induced DWMI. We found that myelin protein levels were significantly lower in Gadd34-null mice exposed to $\mathrm{MCH}$ compared with $\mathrm{MCH}$-exposed controls (Fig. 11A,B), while myelin protein levels were similar between Gadd34-null and control mice exposed to SAH (Fig. 11D,E). We also discovered that while Gadd34 deletion had no effect on p-eIF2 $\alpha$ levels in mice exposed to MCH for $6 \mathrm{~d}$ (Fig. 11C), Gadd34 deletion increased p-eIF $2 \alpha$ levels in mouse brains exposed to SAH for $24 \mathrm{~h}$ (Fig. $11 \mathrm{~F}$ ). In addition to decreased levels of myelin-specific proteins, Gadd34-null mice exposed to $\mathrm{MCH}$ exhibited decreased body weight and increased mortality compared with MCH-exposed Gadd34 WT mice. Gadd34 WT mice exposed to $\mathrm{MCH}$ weighed $7.8 \pm 0.3 \mathrm{~g}$ compared with $5.0 \pm 0.3 \mathrm{~g}$ 
A

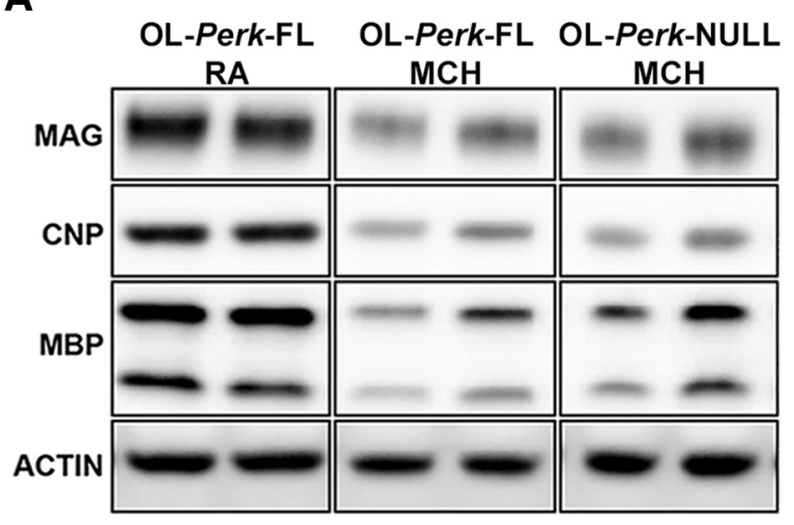

B

B

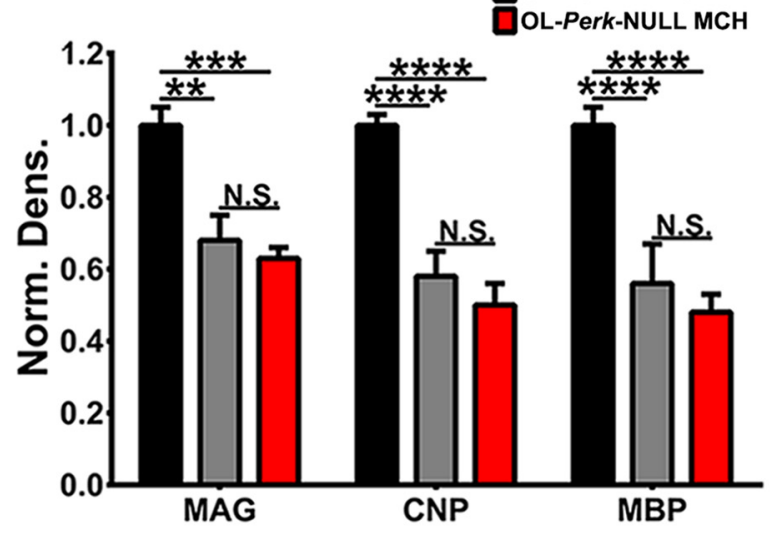

C

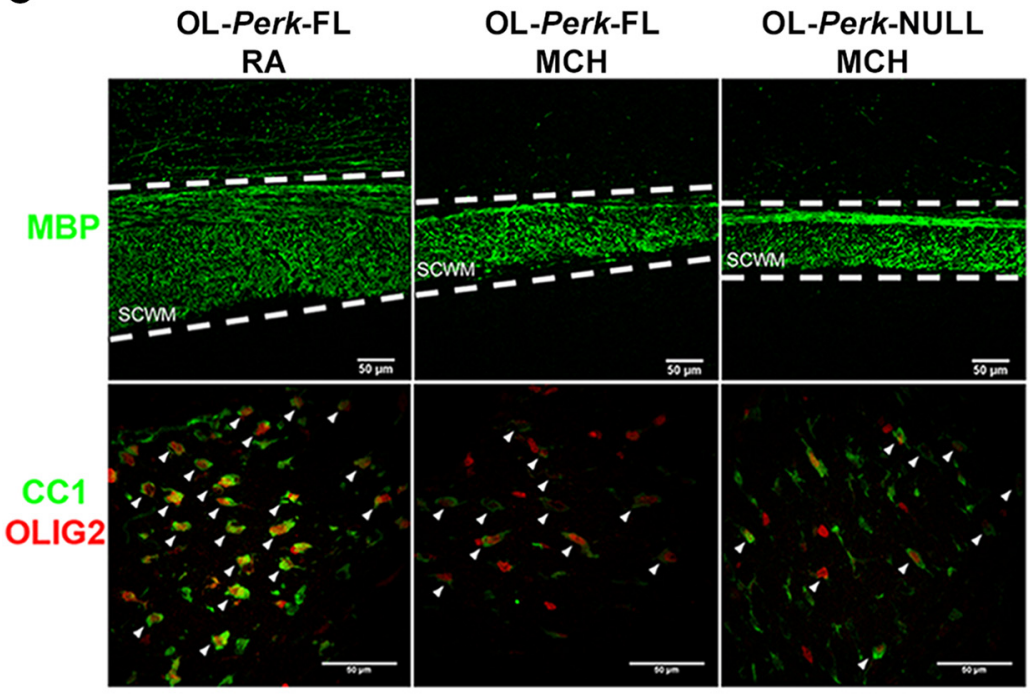

E

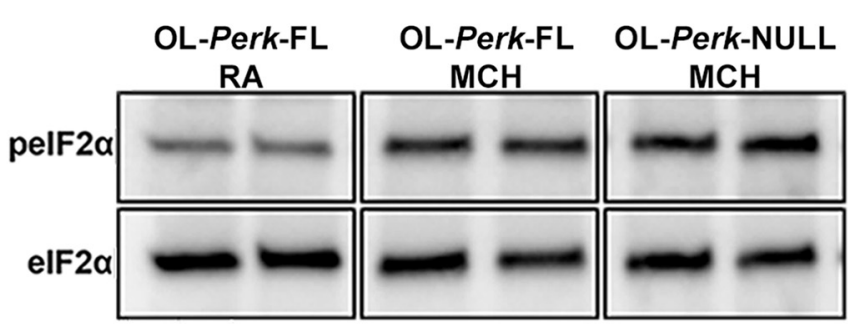

G

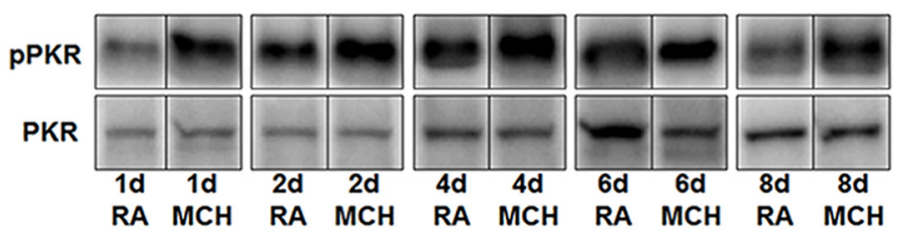

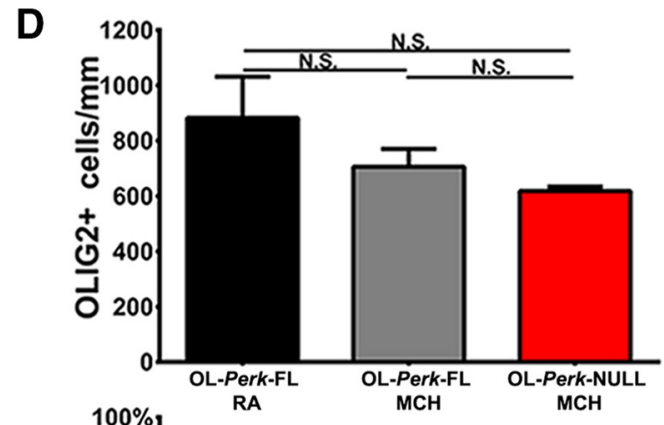

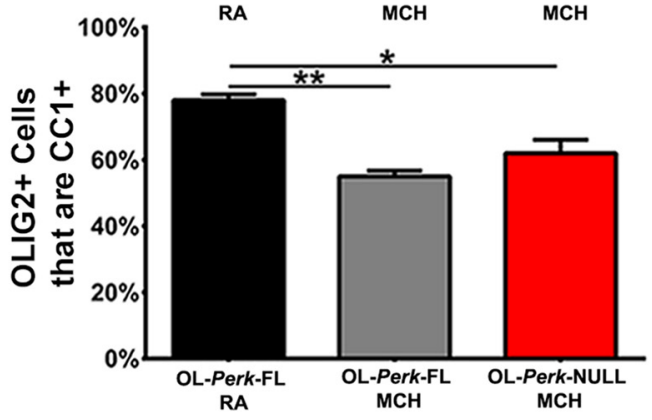

$\mathbf{F}$

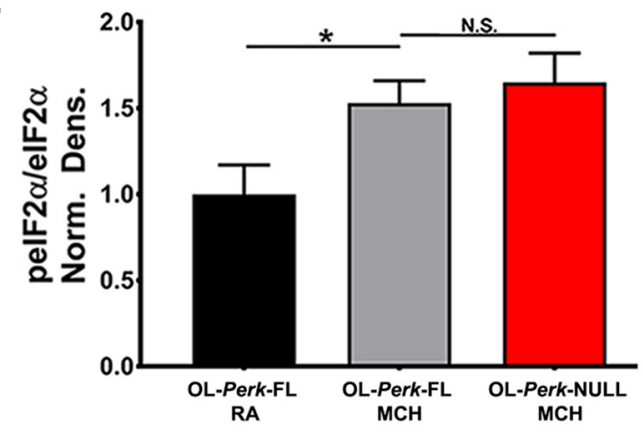

H

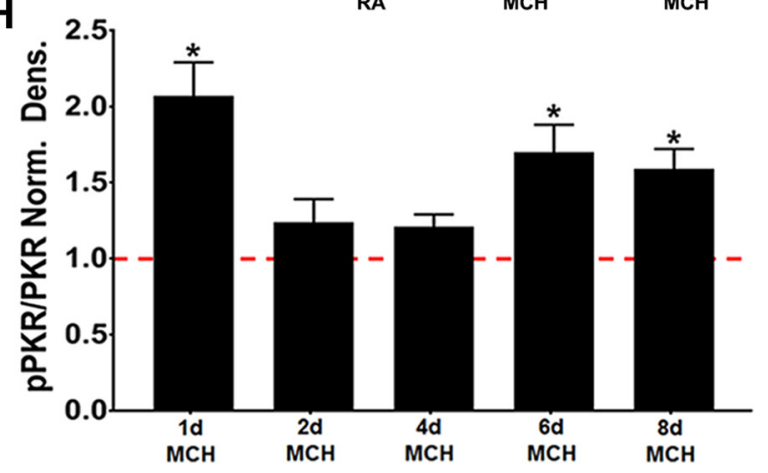


A

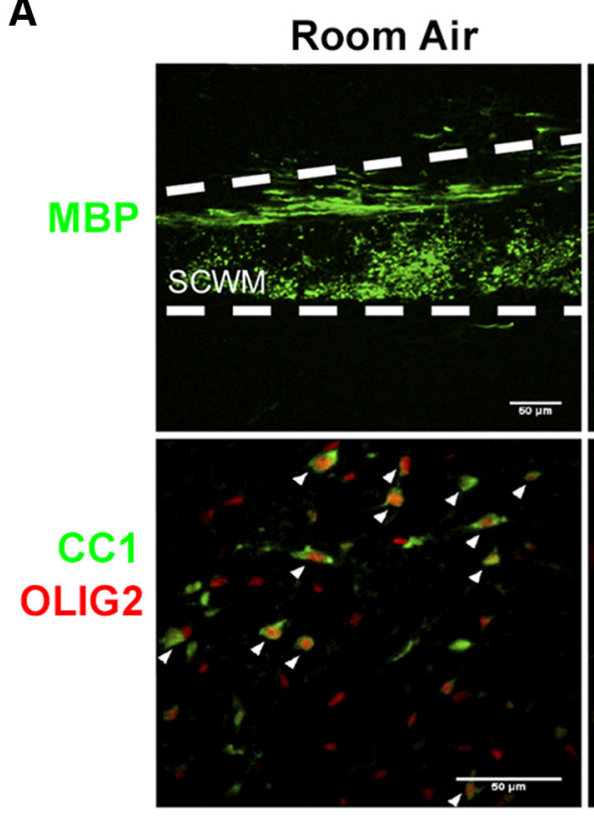

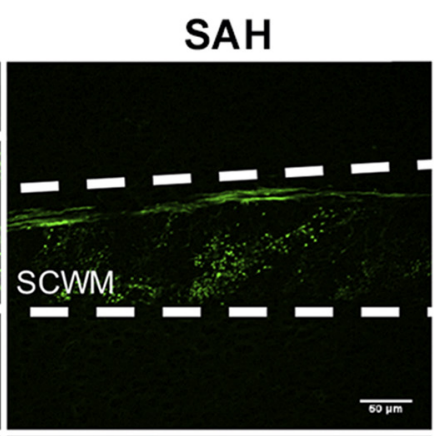

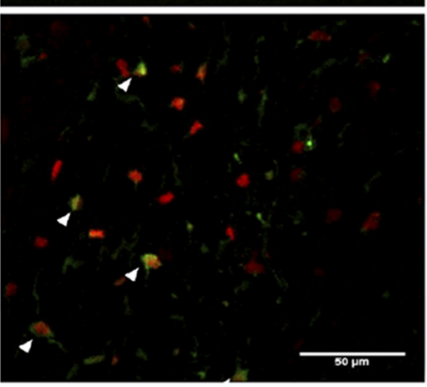

B

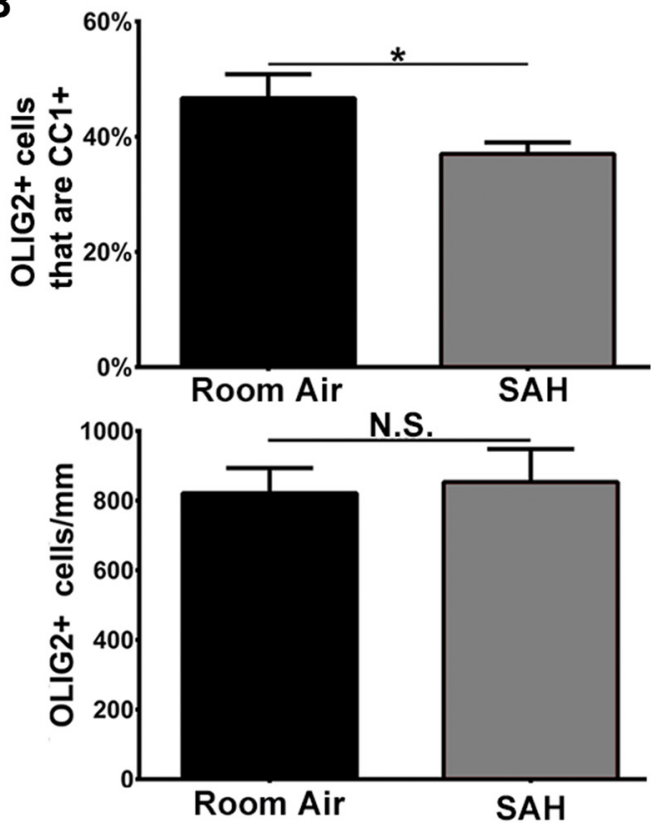

C

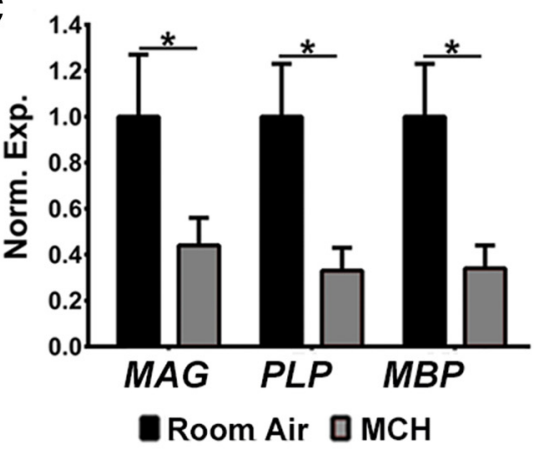

D

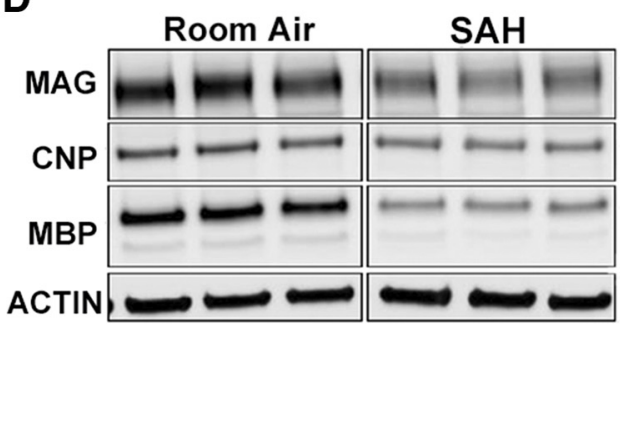

$\mathbf{E}$

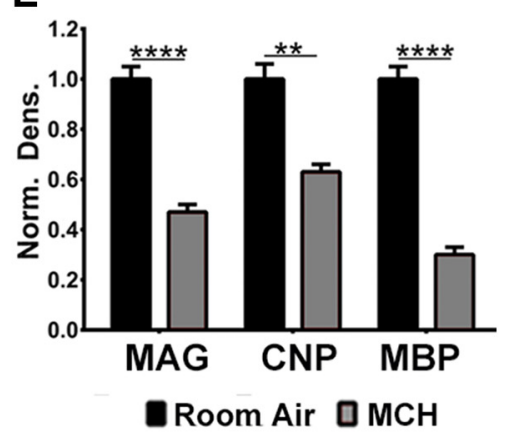

Figure 7. Severe acute hypoxia is an alternative model of diffuse white matter injury. A, Top panels, Representative images of MBP-stained (green) subcortical white matter (SCWM) from P11 mice exposed to SAH or RA control. $A$, Bottom panels, Representative images of mature $\mathrm{CC}^{+}$(green) oligodendrocytes and 0lig2 ${ }^{+}$(red) oligodendrocyte lineage cells from P11 mice exposed to SAH or RA. B, Quantification of the percentage of Olig2 ${ }^{+}$oligodendrocyte lineage cells that are $\mathrm{CC}^{+}{ }^{+}$mature oligodendrocytes and density of 0 lig2 ${ }^{+}$oligodendrocyte lineage cells in P11 SAH-and RA-exposed mice. Data represent $N \geq 3$ mice/group with ${ }^{*} p<0.05$ by unpaired two-tailed $t$ test. C, Analysis of myelin-enriched mRNA Mag, Plp, and Mbp in P4 mice exposed to SAH or RA. Data represent $N \geq 3$ with ${ }^{*} p<0.05$. D, Representative blots of myelin enriched proteins MAG, CNP, and MBP from P11 mice exposed to SAH or RA. E, Quantification of MAG, CNP, and MBP protein levels from P11 mice exposed to SAH or RA. Data represent $N \geq 3$ mice/group with ${ }^{* *} p<0.01$ and ${ }^{* * *} p<0.0001$ by unpaired two-tailed $t$ test. All data are presented as the mean \pm SEM. Scale bar, $50 \mu \mathrm{m}$.

Figure 6. Oligodendrocyte-specific deletion of Perk has no effect on mild chronic hypoxiainduced diffuse white matter injury. $A$, Representative blots of myelin-enriched proteins MAG, CNP, and MBP from P18 OL-Perk-FL and OL-Perk-null mice exposed to MCH and RA control. $B$, Quantification of MAG, CNP, and MBP protein levels from P18 0L-Perk-FL and OL-Perk-null mice exposed to $\mathrm{MCH}$ and RA. Data represent $N \geq 3$ mice/group with ${ }^{* *} p<0.01$, ${ }^{* *} p<$ 0.005 , and ${ }^{* * *} p<0.0001$ by ANOVA with Tukey's post-test. C, Representative images of subcortical white matter (SCWM) from P18 0L-Perk-FL and OL-Perk-null mice exposed to MCH and RA and stained with MBP (green, top panels) or CC1 (green, bottom panels) and 0lig2 (red, bottom panels). $\boldsymbol{D}$, Quantification of the percentage of 0 lig $2^{+}$oligodendrocyte lineage cells that are $\mathrm{CC}^{+}$mature oligodendrocytes and density of Olig2 ${ }^{+}$oligodendrocyte lineage cells in P18 OL-Perk-FL and OL-Perk-null mice exposed to MCH and RA. E, Representative blots of p-elF2 $\alpha$ and elF $2 \alpha$ blots from P7 0L-Perk-FL RA, OL-Perk-FL MCH, and OL-Perk-null MCHexposed mice. $\boldsymbol{F}$, Quantification of p-elF $2 \alpha$ and elF $2 \alpha$ blots. $\boldsymbol{G}$, Representative blots of pPKR and PKR from wild-type mice exposed to $1,2,4,6$, or $8 \mathrm{~d}$ of MCH or RA. $\boldsymbol{H}$, Quantification of pPKR and PKR blots. Data represent $N \geq 3$ mice/group with ${ }^{* *} p<0.01$ and ${ }^{*} p<0.05$ by ANOVA with Tukey's post-test. Scale bar, $50 \mu \mathrm{m}$. Norm. Dens, Normoxia density. for Gadd34-null mice exposed to $\mathrm{MCH}$, and while $85 \%$ of Gadd34 WT mice survived MCH exposure, only 31\% of Gadd34null mice survived. These data raise the possibility that the exacerbated effects of MCH on Gadd34-null mice are systemic and not CNS specific.

$\mathrm{CHOP}$ is known to play a proapoptotic role in response to sustained activation of the ISR (Zinszner et al., 1998), and global Chop deletion protects myelinating Schwann cells in mouse models of Charcot-Marie-Tooth disease (Pennuto et al., 2008). Nevertheless, the role of CHOP in myelinating glia is controversial, and there is evidence to suggest that CHOP expression can be protective in oligodendrocytes (Southwood et al., 2002; Gow and Wrabetz, 2009). To examine whether CHOP plays a role in either MCH- or SAH-induced DWMI, we exposed Chop-null and control mice to $\mathrm{MCH}$ and $\mathrm{SAH}$. We found that Chop deletion had no effect on decreased myelin protein levels caused by either $\mathrm{MCH}$ or SAH (Fig. $11 G-J$ ). These results are in agreement with our findings that Chop is not upregulated by either in vivo model. 
A

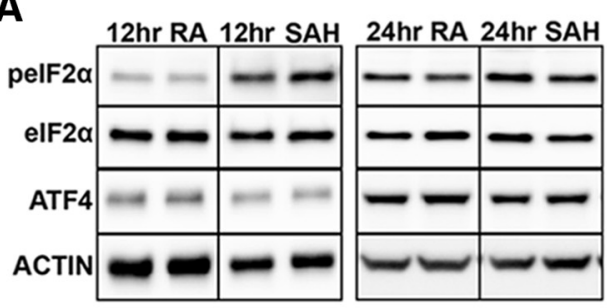

B

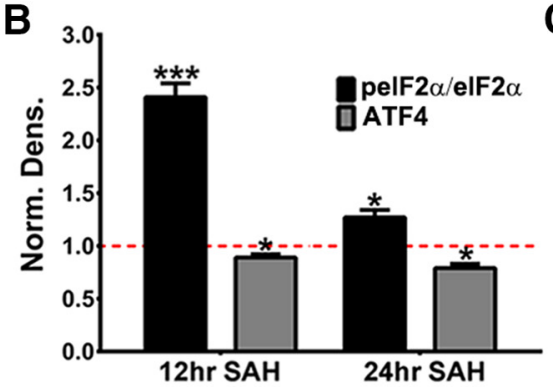

C

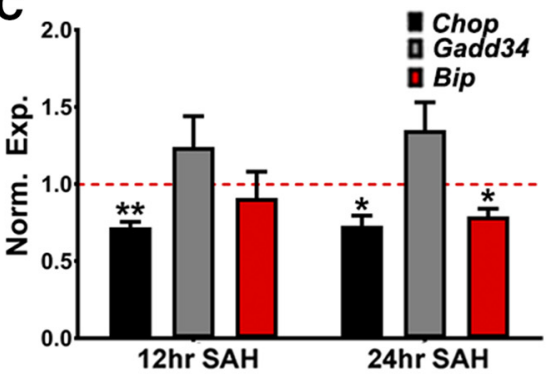

D

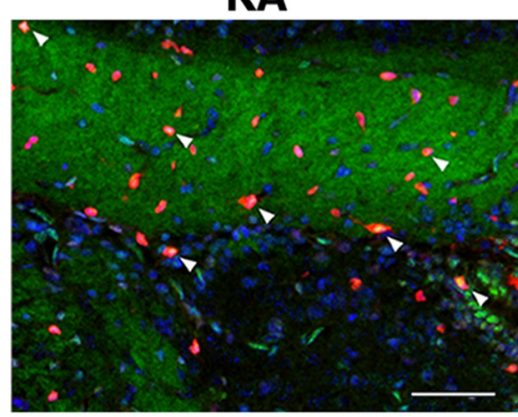

RA

F

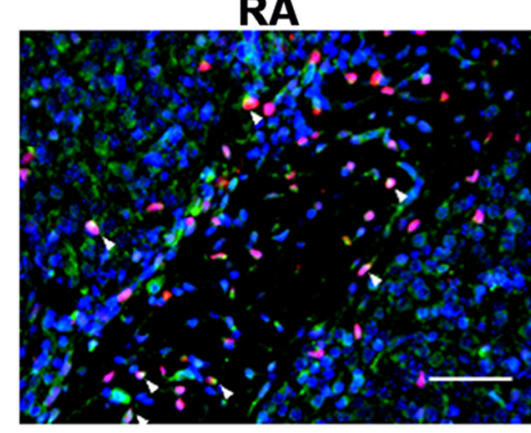

H

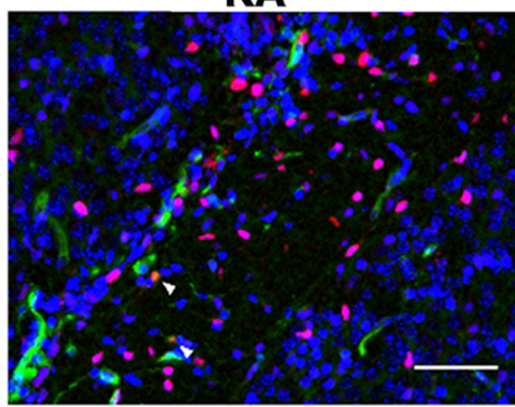

SAH

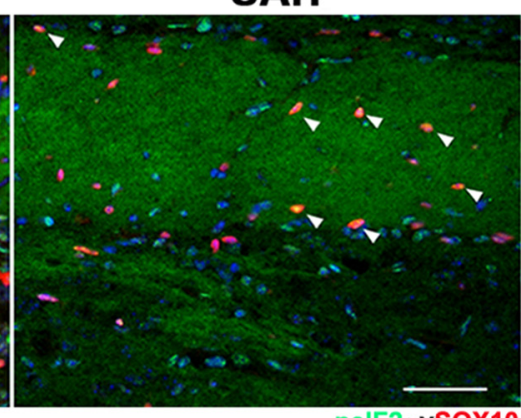

pelF2 $\alpha \mathbf{v S O X 1 0}$

SAH

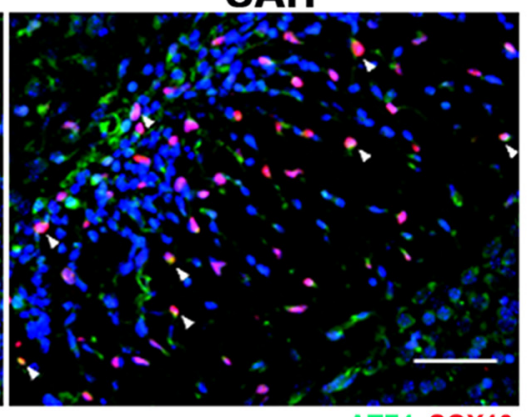

ATF4vSOX10

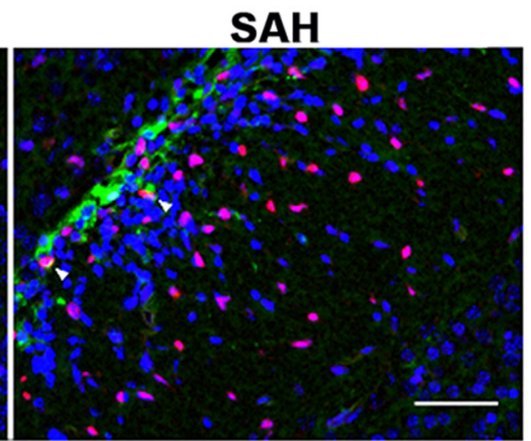

CHOPvSOX10
E

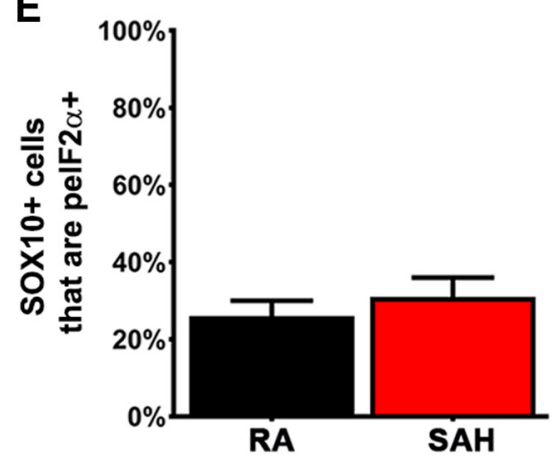

G

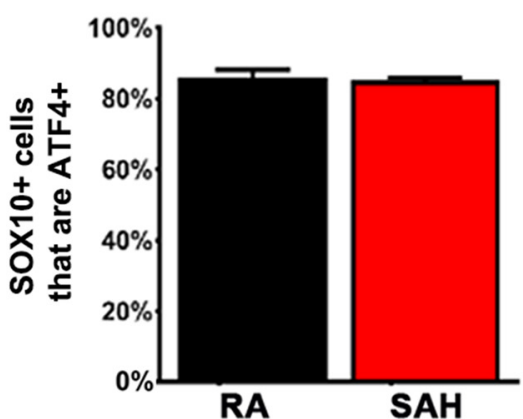

I

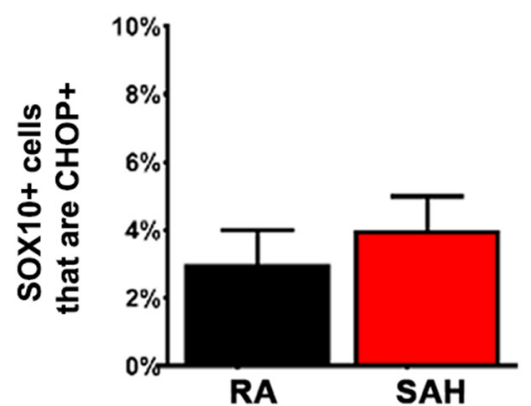

Figure 8. Severe acute hypoxia increases the phosphorylation of elF2 $\alpha$ in the brain but decreases ATF4 protein levels and does not induce downstream ISR components CHOP or GADD34. $\boldsymbol{A}$, Representative p-elF $2 \alpha$, elF $2 \alpha$, and ATF 4 blots from mice exposed to either 12 or $24 \mathrm{~h}$ of SAH or RA control. B, Quantification of p-elF $2 \alpha$, elF $2 \alpha$, and ATF4 protein levels. Data are presented as the p-elF $2 \alpha /$ elF $2 \alpha$ ratio normalized to time-matched RA-exposed control mice. C, Expression of Chop, Gadd34, and Bip mRNA levels normalized to time-matched RA-exposed controls. D, Representative image of SAH- and RA-exposed brains stained with Sox10, a pan-oligodendrocyte lineage cell marker, and p-elF $2 \alpha$. Scale bar, $100 \mu \mathrm{m}$. E, Quantification of Sox $10^{+}$cells that are $\mathrm{p}$-elF2 $\alpha^{+}$. $\boldsymbol{F}$, Representative images of Sox10 and ATF4 staining. Scale bar, $50 \mu \mathrm{m}$. G, Quantification of Sox $10^{+}$cells that are p-elF $2 \alpha^{+}$. H, Representative images of Sox10 and CHOP staining. Scale bar, $50 \mu \mathrm{m}$. I, Quantification of Sox $10^{+}$cells that are $\mathrm{CHOP}^{+}$. All data are presented as the mean \pm SEM for $N \geq 3$ mice/group with ${ }^{*} p<0.05$ compared with time-matched controls (red dashed line) by unpaired two-tailed $t$ test.

\section{Discussion}

The PERK arm of the ISR responds to and protects cells from hypoxia, the main cause of DWMI in premature infants (Liu et al., 2010; Scafidi et al., 2014). PERK is also known to play a protective role in other white matter disorders (Clayton and Popko,
2016; Way and Popko, 2016). This has led to an interest in whether the ISR might play a role in DWMI and whether this cytoprotective pathway could be a therapeutic target for this disorder (Bueter et al., 2009). In the current study, we demonstrate that hypoxia increases phosphorylation of eIF2 $\alpha$ in isolated 
A

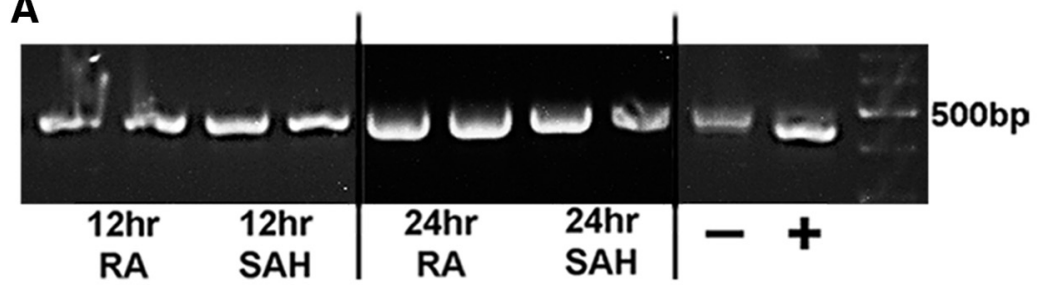

B

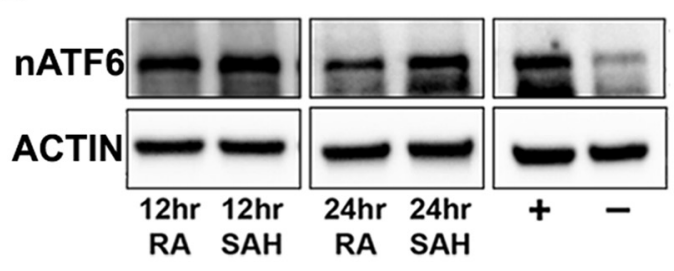

C

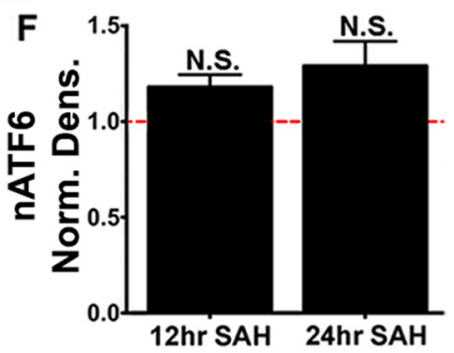

D

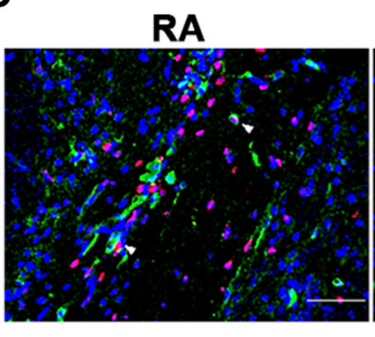

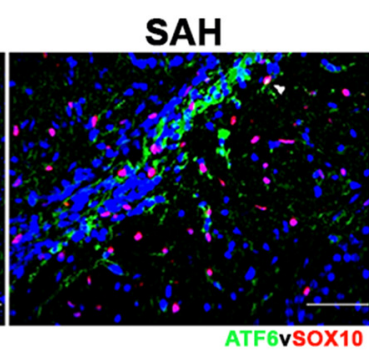

E

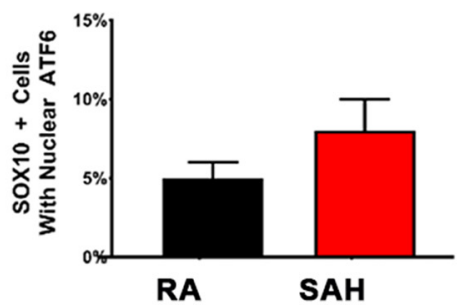

Figure 9. Mild chronic hypoxia does not activate the IRE-1 or ATF6 arms of the unfolded protein response. A, Representative Xbp 1 PCR gel image of mice exposed to SAH or RA. Unspliced Xbp1 product size of $480 \mathrm{bp}$ and spliced Xbp 1 product size of $454 \mathrm{bp}$. Lines represent where images from different gels have been cropped and spliced together. $\boldsymbol{B}$, Representative ATF6 blots from mice exposed to either 12 or $24 \mathrm{~h}$ of SAH or RA. C, Quantification of ATF6 protein levels normalized to time-matched RA-exposed controls. D, Representative images from mouse subcortical white matter stained with ATF6 versus the oligodendrocyte lineage marker Sox10. E, Quantification of the percentage of Sox $10^{+}$cells that are nuclear ATF6 ${ }^{+}$. All data are presented as the mean \pm SEM for $N \geq 3$ mice/group. Scale bar, $50 \mu \mathrm{m}$. Norm. Dens., Normoxia density.

OPCs in vitro and that this is diminished in Perk KO OPCs, leading to increased susceptibility to in vitro hypoxia. Moreover, we show that both MCH and SAH increase the levels of p-eIF $2 \alpha$ in the brain of neonatal mice, without activation of downstream ISR components or the other arms of the UPR. In fact, there were decreased protein levels of the ISR transcription factor ATF4 in the CNS in response to $\mathrm{MCH}$ and SAH. Finally, we demonstrate that oligodendrocyte-specific deletion of Perk had no detectable effect on $\mathrm{MCH}$ - or SAH-induced DWMI. It is possible that the loss of PERK is compensated for by the activation of other hypoxia-responsive eIF2 $\alpha$ kinases (Taniuchi et al., 2016). In fact, we detected increased levels of phosphorylated PKR in brains exposed to either $\mathrm{MCH}$ or SAH. Together, these studies show that although PERK plays a role in oligodendrocyte lineage cells exposed to in vitro hypoxia, PERK signaling within oligodendrocytes does not likely play a crucial role in either in vivo model of DWMI.

PERK-mediated increased phosphorylation of eIF $2 \alpha$ in response to hypoxia occurs in cell lines in vitro (Koumenis et al., 2002). We have demonstrated that in primary isolated OPCs, in vitro hypoxia also increases the phosphorylation of eIF $2 \alpha$ in a mostly PERK-dependent manner. Nonetheless, some increase in phosphorylation of eIF $2 \alpha$ was still seen in Perk KO OPCs exposed to in vitro hypoxia. This may be due to the overlap among the stress-sensing eIF $2 \alpha$ kinases. For example, GCN2 has also been shown to respond to in vitro hypoxia (Liu et al., 2010; Donnelly et al., 2013). Regardless of the potential activation of other eIF $2 \alpha$ kinases, Perk KO OPCs still showed a significantly increased susceptibility to in vitro hypoxia, demonstrating that PERK activity is critical for OPC survival in the face of hypoxia.

In an inflammatory context where PERK activation is shown to increase p-eIF $2 \alpha$ levels, it has also been shown that oligodendrocytespecific PERK insufficiency increases the susceptibility of these cells to inflammation (Lin et al., 2007, 2013, 2014; Hussien et al., 2014). Nonetheless, we found that although in vivo $\mathrm{MCH}$ increased eIF2 $\alpha$ phosphorylation in neonatal mouse brains, oligodendrocyte- specific deletion of Perk did not have a detectable effect on $\mathrm{MCH}$ induced DWMI. The disparate results generated by in vitro and in vivo hypoxia could be due to the severity of the hypoxic stress. Although we were unable to directly measure the percentage of oxygen available to oligodendrocyte lineage cells during $\mathrm{MCH}$ in vivo, it is unlikely to reach the level of oxygen deficiency experienced by oligodendrocyte lineage cells in vitro. In vitro hypoxia allows for a much more severe level of hypoxia without the confounding factor of the systemic effects of hypoxia on survival in vivo. To address this, we developed the SAH model of DWMI where we exposed pups to $7 \pm$ $0.5 \%$ oxygen for $24 \mathrm{~h}$. The $7 \%$ oxygen set point was used as it was the lowest percentage of oxygen tolerated by the lactating females over a $24 \mathrm{~h}$ period. Even with the increased severity of hypoxia, oligodendrocyte-specific deletion of Perk had no effect on the DWMI caused by SAH. While our studies were performed in neonatal mice, it is possible that in the adult mouse the ISR may play a more significant role in response to hypoxic insult. Together, these results suggest that PERK signaling specifically within the oligodendrocyte lineage does not play a pivotal role in neonatal hypoxiainduced DWMI.

It is interesting that while both $\mathrm{MCH}$ and SAH lead to a transient increase in p-eIF2 $\alpha$ levels in whole-brain lysate, neither hypoxic insult causes the induction of a full ISR response. We discovered that the lack of activation of downstream ISR signaling was correlated with hypoxia-driven decreased ATF4 protein levels in whole brain. The decrease in ATF4 protein levels corresponded to the duration of hypoxia in which p-eIF $2 \alpha$ levels were increased. Activation of a truncated ISR is not unprecedented: cells exposed to UV irradiation have been shown to phosphorylate eIF $2 \alpha$ without increasing levels of downstream ISR components (Dey et al., 2010, 2012). It is possible that while the survival response to hypoxia requires phosphorylation of eIF $2 \alpha$ and energy conservation via decreased protein translation, an adaptive transcriptional response driven by ATF4 is expendable.

The major transcriptional regulator in response to hypoxia is hypoxia-inducible factor 1- $\alpha$ (HIF1 $\alpha$ ), which is stabilized under 
A

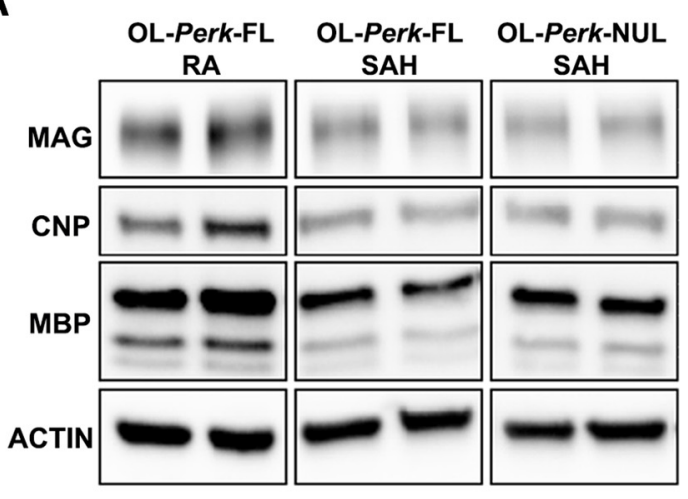

B

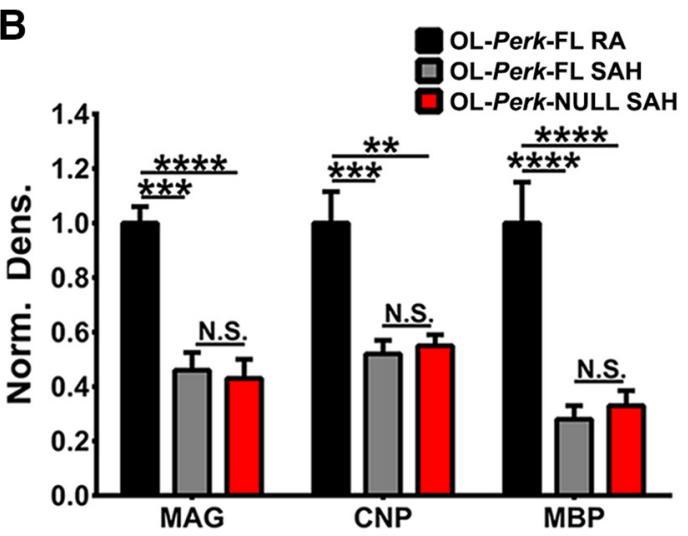

C
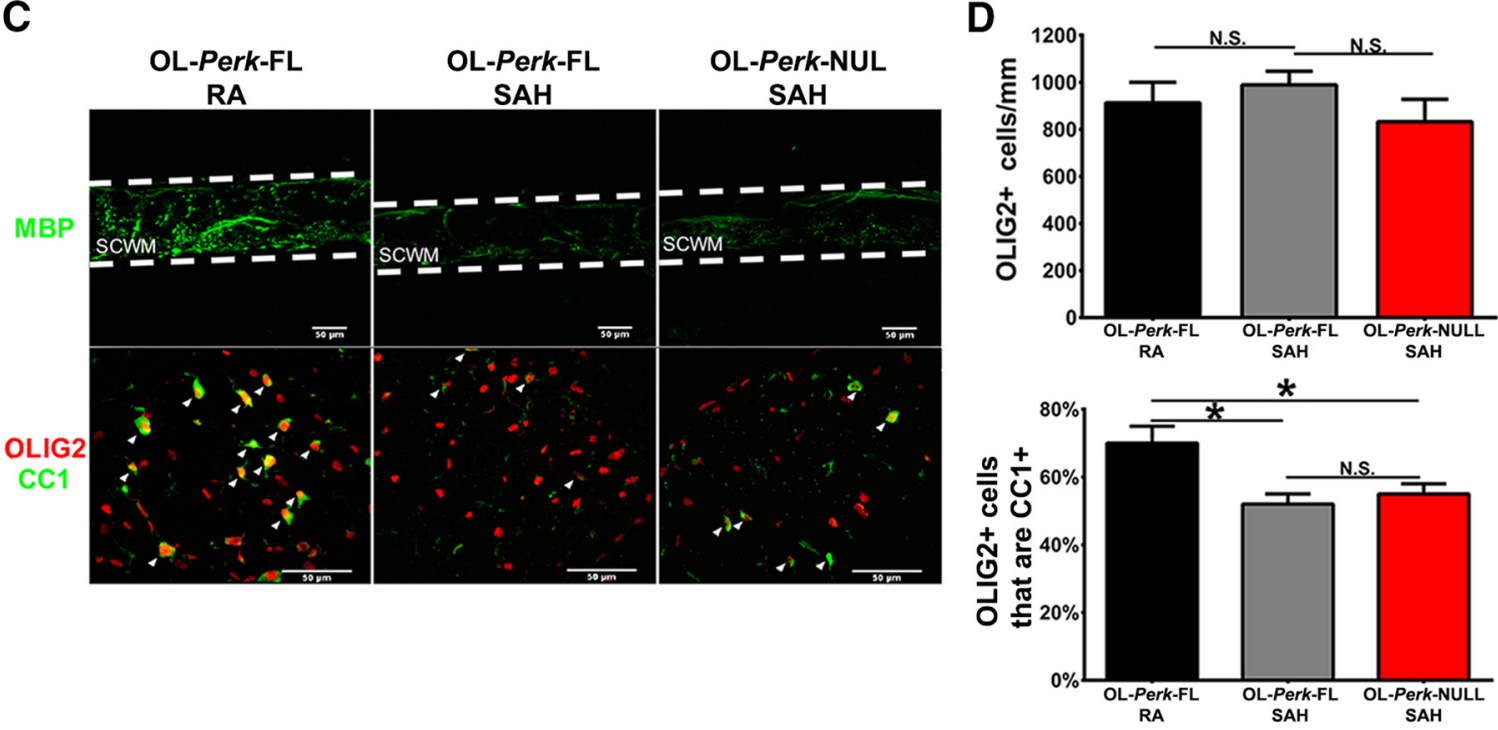

E

OL-Perk-FL OL-Perk-FL OL-Perk-NULL
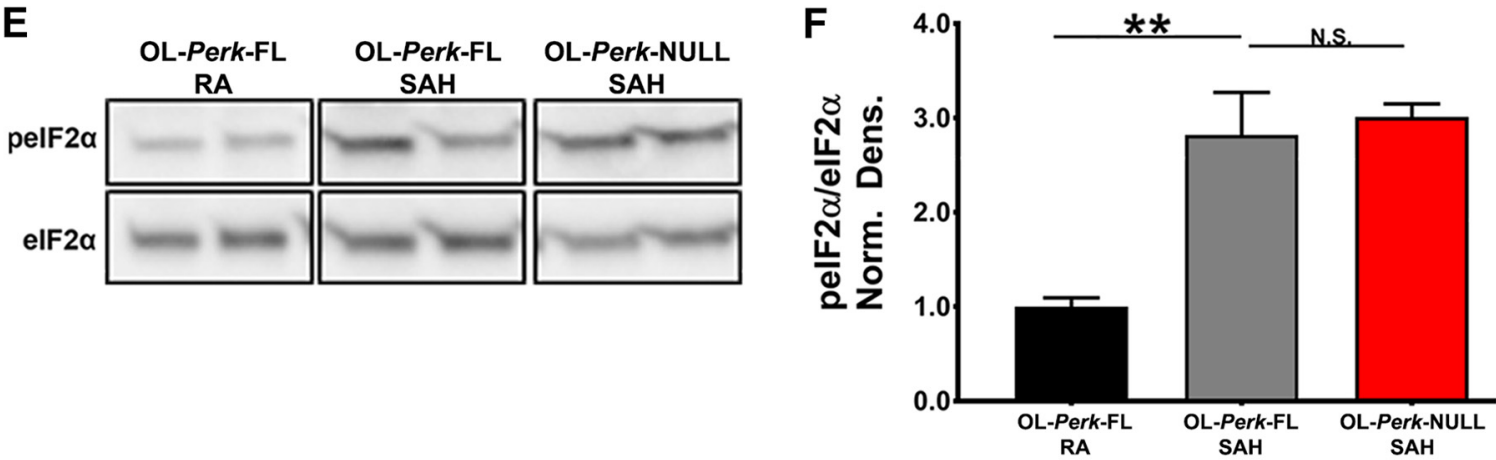

G
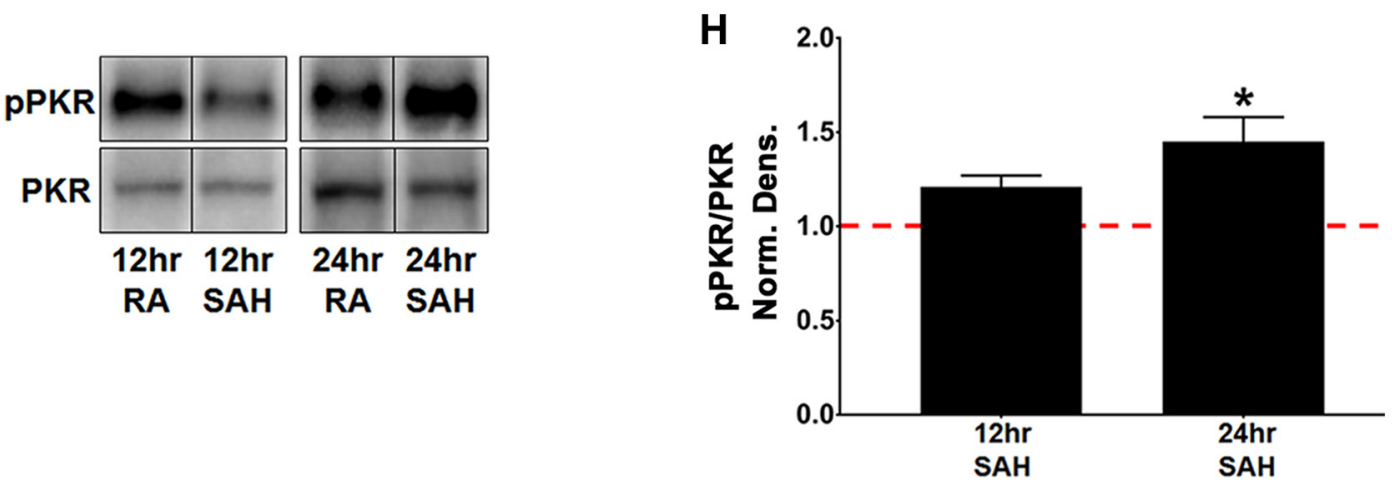

Figure 10. Oligodendrocyte-specific deletion of Perk has no effect on severe acute hypoxia-induced diffuse white matter injury. $A$, Representative blots of MAG, CNP, and MBP from P11 OL-Perk-FL and OL-Perk-null mice exposed to SAH and RA control. B, Quantification of MAG, CNP, and MBP protein levels from P11 0L-Perk-FL and (Figure legend continues.) 
A

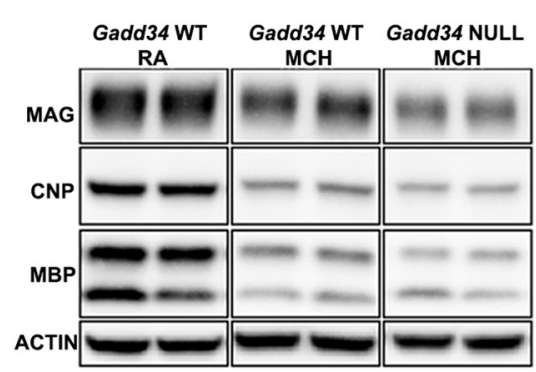

D

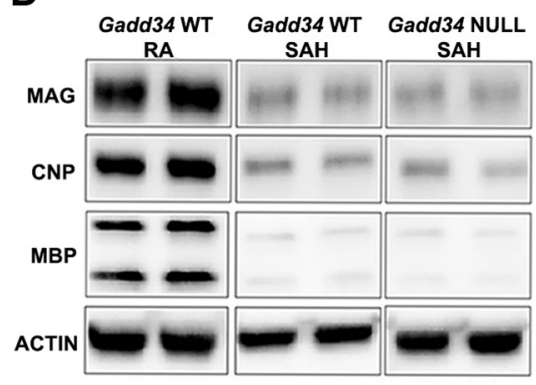

B

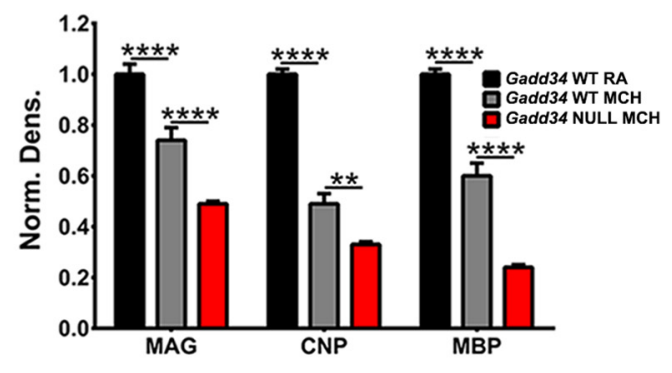

E

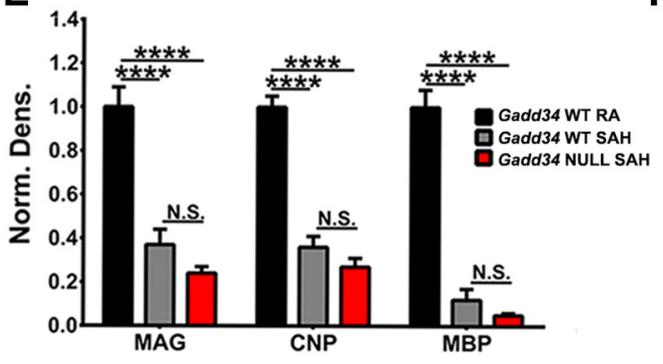

C

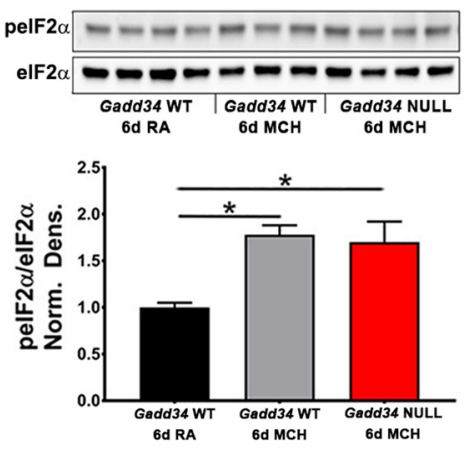

F
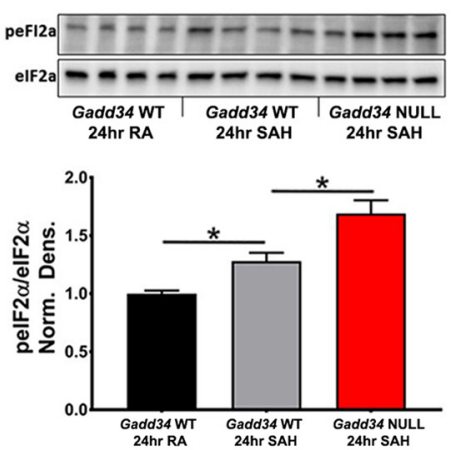

G H
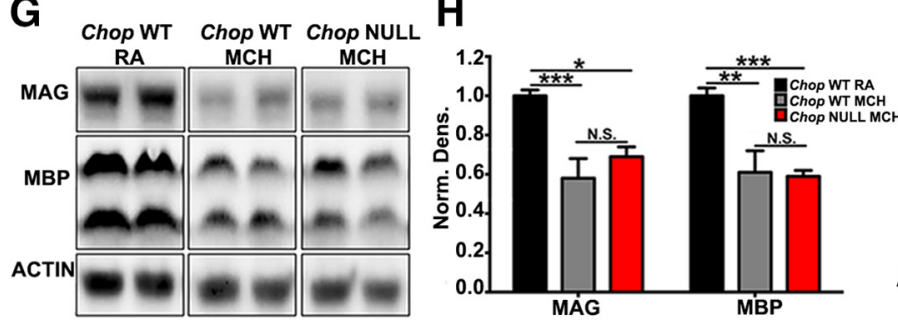

I

J
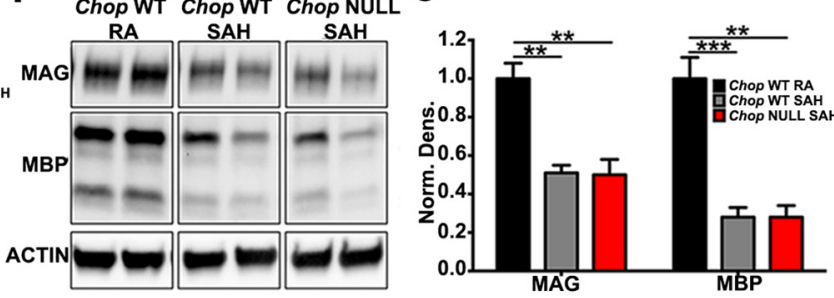

Figure 11. Genetic deletion of Gadd34 or Chop does not protect mice from diffuse white matter injury caused by mild chronic hypoxia or severe acute hypoxia. $A$, Representative blots of myelin proteins MAG, CNP, and MBP from P18 Gadd34-null and Gadd34 WT mice exposed to MCH or RA. B, Quantification of MAG, CNP, and MBP protein levels from P18 Gadd34-null and Gadd34 WT mice exposed to MCH or RA. Data represent $N \geq 3$ mice/group with ${ }^{* *} p<0.01,{ }^{* * *} p<0.005$, and ${ }^{* * *} p<0.0001$ by ANOVA with Tukey's post-test. C, Representative blots and corresponding quantification of p-elF2 $\alpha$ and elF2 $\alpha$ protein in Gadd34 WT and Gadd34-null mice exposed to $6 \mathrm{~d}$ of MCH. D. Representative blots of myelin proteins from P11 Gadd34-null and Gadd34 WT mice exposed to SAHH or RA. E, Quantification of myelin protein levels from P11 Gadd34-null and Gadd34 WT mice exposed to SAH or RA. $\boldsymbol{F}$, Representative blots and corresponding quantification of p-elF2 $\alpha$ and elF2 $\alpha$ protein in Gadd34 WT and Gadd34-null mice exposed to $24 \mathrm{hSAH}$. G, Representative blots of myelin proteins MAG and MBP from P18 Chop-null and Chop WT mice exposed to MCH or RA. H, Quantification of myelin protein levels from P18 Chop-null and Chop WT mice exposed to MCH or RA. I, Representative blots of myelin proteins from P11 Chop-null and Chop WT mice exposed to SAH or RA.J, Quantification of myelin protein levels from P11 Chop-null and Chop WT mice exposed to SAH or RA. Data represent $N \geq 3$ mice/group with ${ }^{*} p<0.05$, ${ }^{* *} p<0.01$, and ${ }^{* * *} p<0.005$ by ANOVA with Tukey's post-test.

hypoxic conditions and induces the expression of genes with hypoxic response elements like vascular endothelial growth factor (VEGF; Sharp and Bernaudin, 2004). It is possible that under hypoxic conditions ATF4 is expendable due to an overlap with

$\leftarrow$

(Figure legend continued.) OL-Perk-null mice exposed to SAH and RA. Data represent $N \geq 3$ mice/group with ${ }^{* *} p<0.01,{ }^{* *} p<0.005$, and ${ }^{* * *} p<0.0001$ by ANOVA with Tukey's post-test. C, Representative images of subcortical white matter (SCWM) from P11 OL-Perk-FL and $0 \mathrm{~L}-$ Perk-null mice exposed to SAH and RA and stained with MBP (green, top panels) or CC1 (green, bottom panels) and Olig2 (red, bottom panels). D, Quantification of the percentage of Olig2 ${ }^{+}$oligodendrocyte lineage cells that are $\mathrm{CC}^{+}$mature oligodendrocytes and the density of Olig2 ${ }^{+}$oligodendrocyte lineage cells in P11 0L-Perk-FL and OL-Perk-null mice exposed to SAH and RA. $E$, Representative blots of $\mathrm{p}$-elF $2 \alpha$ and elF $2 \alpha$ from $0 \mathrm{~L}-$ Perk-FL RA, $0 \mathrm{~L}-$ Perk-FL $\mathrm{MCH}$, and $0 \mathrm{~L}-$ Perk-null mice exposed to $12 \mathrm{~h}$ of SAH. $\boldsymbol{F}$, Quantification of $\mathrm{p}$-elF $2 \alpha$ and elF $2 \alpha$ blots. G, Representative blots of pPKR and PKR from wild-type mice exposed to 1, 2, 4, 6, or $8 \mathrm{~d}$ of MCH or RA. $\boldsymbol{H}$, Quantification of pPKR and PKR blots. Data represent $N \geq 3$ mice/group with ${ }^{* *} p<0.01$ and ${ }^{*} p<0.05$ by ANOVA with Tukey's post-test. Scale bars, $50 \mu \mathrm{m}$. Norm. Dens., Normoxia density.
HIF $1 \alpha$ targets. In fact, it has been shown that the ISR increases expression of the HIF $1 \alpha$ target gene Vegf (Ghosh et al., 2010). In addition, genetic removal of $H i f 1 \alpha$ increases baseline expression of ATF4, suggesting that HIF $1 \alpha$ is a negative regulator of ATF4 expression (Guimarães-Camboa et al., 2015). Therefore, the truncated activation of the ISR by hypoxia may be the result of ATF4 inhibition by $\operatorname{HIF} 1 \alpha$.

Our results also show that phosphorylation of $\operatorname{eIF} 2 \alpha$ in response to hypoxia is transient. It has been shown that translational inhibition in response to hypoxia exhibits a biphasic response, with the initial inhibition of protein translation caused by the phosphorylation of eIF2 $\alpha$ (Wouters et al., 2005; van den Beucken et al., 2006). Perhaps the transient nature of hypoxiainduced eIF $2 \alpha$ phosphorylation is due to activation of the negative feedback loop culminating in dephosphorylation of eIF $2 \alpha$. Our data support this possibility in that Gadd34-null mice have higher levels of p-eIF2 $\alpha$ after $24 \mathrm{~h}$ of SAH than controls. The lack of an apparent effect of the Gadd34 mutation on MCH-induced 
p-eIF $2 \alpha$ levels is potentially due to the possibility that we did not assess an appropriate time point.

Inhibition of GADD34 is known to be protective in mouse models of multiple sclerosis, and Chop deletion protects myelinating Schwann cells in mouse models of Charcot-Marie-Tooth disease (Pennuto et al., 2008; Way et al., 2015). We found that, in agreement with the lack of increased Chop expression, Chop deletion had no detectable effect on DWMI, while the effect of global Gadd34 deletion was dependent on the hypoxic insult. GADD34 acts as a regulatory subunit for protein phosphatase 1 and is responsible for dephosphorylation of $\operatorname{eIF} 2 \alpha$. Therefore, inhibition of GADD34 enhances the ISR by prolonging the phosphorylation of eIF $2 \alpha$ (Novoa et al., 2001). Multiple genetic and pharmacological approaches have shown that Gadd34 inhibition is protective in disorders of myelinating glia, including oligodendrocytes (Lin et al., 2008; D’Antonio et al., 2013; Way et al., 2015). Using a global Gadd34-null mutant, we found that GADD34 inactivation is detrimental in the case of MCH. Gadd34-null mice exposed to $\mathrm{MCH}$ had decreased levels of myelin proteins, decreased total body weight, and increased mortality compared with Gadd34 WT mice exposed to MCH. Surprisingly, Gadd34null mice exposed to SAH showed no measurable difference when compared with Gadd34 WT mice exposed to SAH. This suggests that the combined effects of global Gadd34 deletion and a chronic hypoxic stress is detrimental, perhaps due to an impaired ability to adapt to the hypoxic environment. In support of this possibility, Gadd34 mutant mice were shown to have impaired hemoglobin production (Patterson et al., 2006). Impaired hemoglobin synthesis could explain the increased susceptibility of the Gadd34-null mice to hypoxia. Preliminary data from our laboratory support this possibility: we have found that, when exposed to MCH, Gadd34-null mice have a decreased hematopoietic response that is characterized by decreased hemoglobin and red blood cell production when compared with Gadd34 WT mice exposed to MCH (data not shown).

In summary, we have investigated the role of the ISR, a protective pathway that responds to a variety of cytotoxic insults, in both in vitro and in vivo hypoxia-induced models of DWMI. We found that while PERK is critical to protect oligodendrocyte lineage cells from hypoxia in vitro, its removal had no measurable effect on hypoxia-induced DWMI in vivo. Moreover, the enhancement of the ISR via GADD34 or CHOP inactivation did not provide increased protection in models of DWMI. These results suggest that targeting the PERK arm of the ISR would not likely be an effective strategy for DWMI therapy.

\section{References}

Back SA (2015) Brain injury in the preterm infant: new horizons for pathogenesis and prevention. Pediatr Neurol 53:185-192. CrossRef Medline

Back SA, Miller SP (2014) Brain injury in premature neonates: a primary cerebral dysmaturation disorder? Ann Neurol 75:469-486. CrossRef Medline

Back SA, Luo NL, Borenstein NS, Levine JM, Volpe JJ, Kinney HC (2001) Late oligodendrocyte progenitors coincide with the developmental window of vulnerability for human perinatal white matter injury. J Neurosci 21:1302-1312. Medline

Back SA, Han BH, Luo NL, Chricton CA, Xanthoudakis S, Tam J, Arvin KL, Holtzman DM (2002) Selective vulnerability of late oligodendrocyte progenitors to hypoxia-ischemia. J Neurosci 22:455-463. Medline

Back SA, Luo NL, Mallinson RA, O’Malley JP, Wallen LD, Frei B, Morrow JD, Petito CK, Roberts CT Jr, Murdoch GH, Montine TJ (2005) Selective vulnerability of preterm white matter to oxidative damage defined by F2-isoprostanes. Ann Neurol 58:108-120. CrossRef Medline

Back SA, Riddle A, McClure MM (2007) Maturation-dependent vulnerability of perinatal white matter in premature birth. Stroke 38:724-730. CrossRef Medline
Barres BA, Hart IK, Coles HS, Burne JF, Voyvodic JT, Richardson WD, Raff MC (1992) Cell death and control of cell survival in the oligodendrocyte lineage. Cell 70:31-46. CrossRef Medline

Blais JD, Addison CL, Edge R, Falls T, Zhao H, Wary K, Koumenis C, Harding HP, Ron D, Holcik M, Bell JC (2006) Perk-dependent translational regulation promotes tumor cell adaptation and angiogenesis in response to hypoxic stress. Mol Cell Biol 26:9517-9532. CrossRef Medline

Bueter W, Dammann O, Leviton A (2009) Endoplasmic reticulum stress, inflammation, and perinatal brain damage. Pediatr Res 66:487-494. CrossRef Medline

Clayton BL, Popko B (2016) Endoplasmic reticulum stress and the unfolded protein response in disorders of myelinating glia. Brain Res 1648:594602. CrossRef Medline

D’Antonio M, Musner N, Scapin C, Ungaro D, Del Carro U, Ron D, Feltri ML, Wrabetz L (2013) Resetting translational homeostasis restores myelination in Charcot-Marie-Tooth disease type 1B mice. J Exp Med 210: 821-838. CrossRef Medline

Deng W (2010) Neurobiology of injury to the developing brain. Nat Rev Neurol 6:328-336. CrossRef Medline

Dey S, Baird TD, Zhou D, Palam LR, Spandau DF, Wek RC (2010) Both transcriptional regulation and translational control of ATF4 are central to the integrated stress response. J Biol Chem 285:33165-33174. CrossRef Medline

Dey S, Savant S, Teske BF, Hatzoglou M, Calkhoven CF, Wek RC (2012) Transcriptional repression of ATF4 gene by CCAAT/enhancer-binding protein $\beta(\mathrm{C} / \mathrm{EBP} \beta)$ differentially regulates integrated stress response. J Biol Chem 287:21936-21949. CrossRef Medline

Donnelly N, Gorman AM, Gupta S, Samali A (2013) The eIF2 $\alpha$ kinases: their structures and functions. Cell Mol Life Sci 70:3493-3511. CrossRef Medline

Dugas JC, Emery B (2013a) Purification of oligodendrocyte precursor cells from rat cortices by immunopanning. Cold Spring Harb Protoc 2013: 745-758. CrossRef Medline

Dugas JC, Emery B (2013b) Purification and culture of oligodendrocyte lineage cells. Cold Spring Harb Protoc 2013:810-814. CrossRef Medline

Emery B, Dugas JC (2013) Purification of oligodendrocyte lineage cells from mouse cortices by immunopanning. Cold Spring Harb Protoc 2013: 854-868. CrossRef Medline

Fagel DM, Ganat Y, Silbereis J, Ebbitt T, Stewart W, Zhang H, Ment LR, Vaccarino FM (2006) Cortical neurogenesis enhanced by chronic perinatal hypoxia. Exp Neurol 199:77-91. CrossRef Medline

Fancy SP, Harrington EP, Yuen TJ, Silbereis JC, Zhao C, Baranzini SE, Bruce CC, Otero JJ, Huang EJ, Nusse R, Franklin RJ, Rowitch DH (2011) Axin2 as regulatory and therapeutic target in newborn brain injury and remyelination. Nat Neurosci 14:1009-1016. CrossRef Medline

Ghosh R, Lipson KL, Sargent KE, Mercurio AM, Hunt JS, Ron D, Urano F (2010) Transcriptional regulation of VEGF-A by the unfolded protein response pathway. PLoS One 5:e9575. CrossRef Medline

Gow A, Wrabetz L (2009) CHOP and the endoplasmic reticulum stress response in myelinating glia. Curr Opin Neurobiol 19:505-510. CrossRef Medline

Guimarães-Camboa N, Stowe J, Aneas I, Sakabe N, Cattaneo P, Henderson L, Kilberg MS, Johnson RS, Chen J, McCulloch AD, Nobrega MA, Evans SM, Zambon AC (2015) HIF1 $\alpha$ represses cell stress pathways to allow proliferation of hypoxic fetal cardiomyocytes. Dev Cell 33:507-521. CrossRef Medline

Harding HP, Zhang Y, Zeng H, Novoa I, Lu PD, Calfon M, Sadri N, Yun C, Popko B, Paules R, Stojdl DF, Bell JC, Hettmann T, Leiden JM, Ron D (2003) An integrated stress response regulates amino acid metabolism and resistance to oxidative stress. Mol Cell 11:619-633. CrossRef Medline

Hetz C, Chevet E, Harding HP (2013) Targeting the unfolded protein response in disease. Nat Rev Drug Discov 12:703-719. CrossRef Medline

Hussien Y, Cavener DR, Popko B (2014) Genetic inactivation of PERK signaling in mouse oligodendrocytes: normal developmental myelination with increased susceptibility to inflammatory demyelination. Glia 62 : 680-691. CrossRef Medline

Hussien Y, Podojil JR, Robinson AP, Lee AS, Miller SD, Popko B (2015) ER chaperone BiP/GRP78 is required for myelinating cell survival and provides protection during experimental autoimmune encephalomyelitis. J Neurosci 35:15921-15933. CrossRef Medline

Jablonska B, Scafidi J, Aguirre A, Vaccarino F, Nguyen V, Borok E, Horvath TL, Rowitch DH, Gallo V (2012) Oligodendrocyte regeneration after 
neonatal hypoxia requires FoxO1-mediated p27Kip1 expression. J Neurosci 32:14775-14793. CrossRef Medline

Koumenis C, Naczki C, Koritzinsky M, Rastani S, Diehl A, Sonenberg N, Koromilas A, Wouters BG (2002) Regulation of protein synthesis by hypoxia via activation of the endoplasmic reticulum kinase PERK and phosphorylation of the translation initiation factor eIF2alpha. Mol Cell Biol 22:7405-7416. CrossRef Medline

Koumenis C, Bi M, Ye J, Feldman D, Koong AC (2007) Hypoxia and the unfolded protein response. Meth Enzymol 435:275-293. CrossRef Medline

Kucharova K, Stallcup WB (2015) NG2-proteoglycan-dependent contributions of oligodendrocyte progenitors and myeloid cells to myelin damage and repair. J Neuroinflammation 12:161. CrossRef Medline

Lin W, Bailey SL, Ho H, Harding HP, Ron D, Miller SD, Popko B (2007) The integrated stress response prevents demyelination by protecting oligodendrocytes against immune-mediated damage. J Clin Invest 117:448456. CrossRef Medline

Lin W, Kunkler PE, Harding HP, Ron D, Kraig RP, Popko B (2008) Enhanced integrated stress response promotes myelinating oligodendrocyte survival in response to interferon-gamma. Am J Pathol 173:1508-1517. CrossRef Medline

Lin W, Lin Y, Li J, Fenstermaker AG, Way SW, Clayton B, Jamison S, Harding HP, Ron D, Popko B (2013) Oligodendrocyte-specific activation of PERK signaling protects mice against experimental autoimmune encephalomyelitis. J Neurosci 33:5980-5991. CrossRef Medline

Lin Y, Huang G, Jamison S, Li J, Harding HP, Ron D, Lin W (2014) PERK activation preserves the viability and function of remyelinating oligodendrocytes in immune-mediated demyelinating diseases. Am J Pathol 184: 507-519. CrossRef Medline

Liu Y, László C, Liu Y, Liu W, Chen X, Evans SC, Wu S (2010) Regulation of G(1) arrest and apoptosis in hypoxia by PERK and GCN2-mediated eIF2alpha phosphorylation. Neoplasia 12:61-68. CrossRef Medline

Martin RJ, Wang K, Köroğlu O, Di Fiore J, Kc P (2011) Intermittent hypoxic episodes in preterm infants: do they matter? Neonatology 100:303-310. CrossRef Medline

Ment LR, Schwartz M, Makuch RW, Stewart WB (1998) Association of chronic sublethal hypoxia with ventriculomegaly in the developing rat brain. Dev Brain Res 111:197-203. CrossRef

Novoa I, Zeng H, Harding HP, Ron D (2001) Feedback inhibition of the unfolded protein response by GADD34-mediated dephosphorylation of eIF2alpha. J Cell Biol 153:1011-1022. CrossRef Medline

Patterson AD, Hollander MC, Miller GF, Fornace AJ Jr (2006) Gadd34 requirement for normal hemoglobin synthesis. Mol Cell Biol 26:16441653. CrossRef Medline

Pennuto M, Tinelli E, Malaguti M, Del Carro U, D’Antonio M, Ron D, Quattrini A, Feltri ML, Wrabetz L (2008) Ablation of the UPR-mediator $\mathrm{CHOP}$ restores motor function and reduces demyelination in CharcotMarie-Tooth 1B mice. Neuron 57:393-405. CrossRef Medline

Pfaffl MW (2001) A new mathematical model for relative quantification in real-time RT-PCR. Nucleic Acids Res 29:e45. CrossRef Medline

Scafidi J, Fagel DM, Ment LR, Vaccarino FM (2009) Modeling premature brain injury and recovery. Int J Dev Neurosci 27:863-871. CrossRef Medline
Scafidi J, Hammond TR, Scafidi S, Ritter J, Jablonska B, Roncal M, SzigetiBuck K, Coman D, Huang Y, McCarter RJ Jr, Hyder F, Horvath TL, Gallo $\mathrm{V}$ (2014) Intranasal epidermal growth factor treatment rescues neonatal brain injury. Nature 506:230-234. CrossRef Medline

Schüller U, Heine VM, Mao J, Kho AT, Dillon AK, Han YG, Huillard E, Sun T, Ligon AH, Qian Y, Ma Q, Alvarez-Buylla A, McMahon AP, Rowitch DH, Ligon KL (2008) Acquisition of granule neuron precursor identity is a critical determinant of progenitor cell competence to form Shhinduced medulloblastoma. Cancer Cell 14:123-134. CrossRef Medline

Sharp FR, Bernaudin M (2004) HIF1 and oxygen sensing in the brain. Nat Rev Neurosci 5:437-448. CrossRef Medline

Southwood CM, Garbern J, Jiang W, Gow A (2002) The unfolded protein response modulates disease severity in Pelizaeus-Merzbacher disease. Neuron 36:585-596. CrossRef Medline

Taniuchi S, Miyake M, Tsugawa K, Oyadomari M, Oyadomari S (2016) Integrated stress response of vertebrates is regulated by four eIF $2 \alpha$ kinases. Sci Rep 6:32886. CrossRef Medline

van den Beucken T, Koritzinsky M, Wouters BG (2006) Translational control of gene expression during hypoxia. Cancer Biol Ther 5:749-755. CrossRef Medline

Volpe JJ (2001) Neurobiology of periventricular leukomalacia in the premature infant. Pediatr Res 50:553-562. CrossRef Medline

Volpe JJ (2009) Brain injury in premature infants: a complex amalgam of destructive and developmental disturbances. Lancet Neurol 8:110-124. CrossRef Medline

Way SW, Popko B (2016) Harnessing the integrated stress response for the treatment of multiple sclerosis. Lancet Neurol 15:434-443. CrossRef Medline

Way SW, Podojil JR, Clayton BL, Zaremba A, Collins TL, Kunjamma RB, Robinson AP, Brugarolas P, Miller RH, Miller SD, Popko B (2015) Pharmaceutical integrated stress response enhancement protects oligodendrocytes and provides a potential multiple sclerosis therapeutic. Nat Commun 6:6532. CrossRef Medline

Wilson-Costello D, Friedman H, Minich N, Fanaroff AA, Hack M (2005) Improved survival rates with increased neurodevelopmental disability for extremely low birth weight infants in the 1990s. Pediatrics 115:997-1003. CrossRef Medline

Wouters BG, van den Beucken T, Magagnin MG, Koritzinsky M, Fels D, Koumenis C (2005) Control of the hypoxic response through regulation of mRNA translation. Semin Cell Dev Biol 16:487-501. CrossRef Medline

Yuen TJ, Silbereis JC, Griveau A, Chang SM, Daneman R, Fancy SP, Zahed H, Maltepe E, Rowitch DH (2014) Oligodendrocyte-encoded HIF function couples postnatal myelination and white matter angiogenesis. Cell 158: 383-396. CrossRef Medline

Zhang P, McGrath B, Li S, Frank A, Zambito F, Reinert J, Gannon M, Ma K, McNaughton K, Cavener DR (2002) The PERK eukaryotic initiation factor 2 alpha kinase is required for the development of the skeletal system, postnatal growth, and the function and viability of the pancreas. Mol Cell Biol 22:3864-3874. CrossRef Medline

Zinszner H, Kuroda M, Wang X, Batchvarova N, Lightfoot RT, Remotti H, Stevens JL, Ron D (1998) CHOP is implicated in programmed cell death in response to impaired function of the endoplasmic reticulum. Genes Dev 12:982-995. CrossRef Medline 